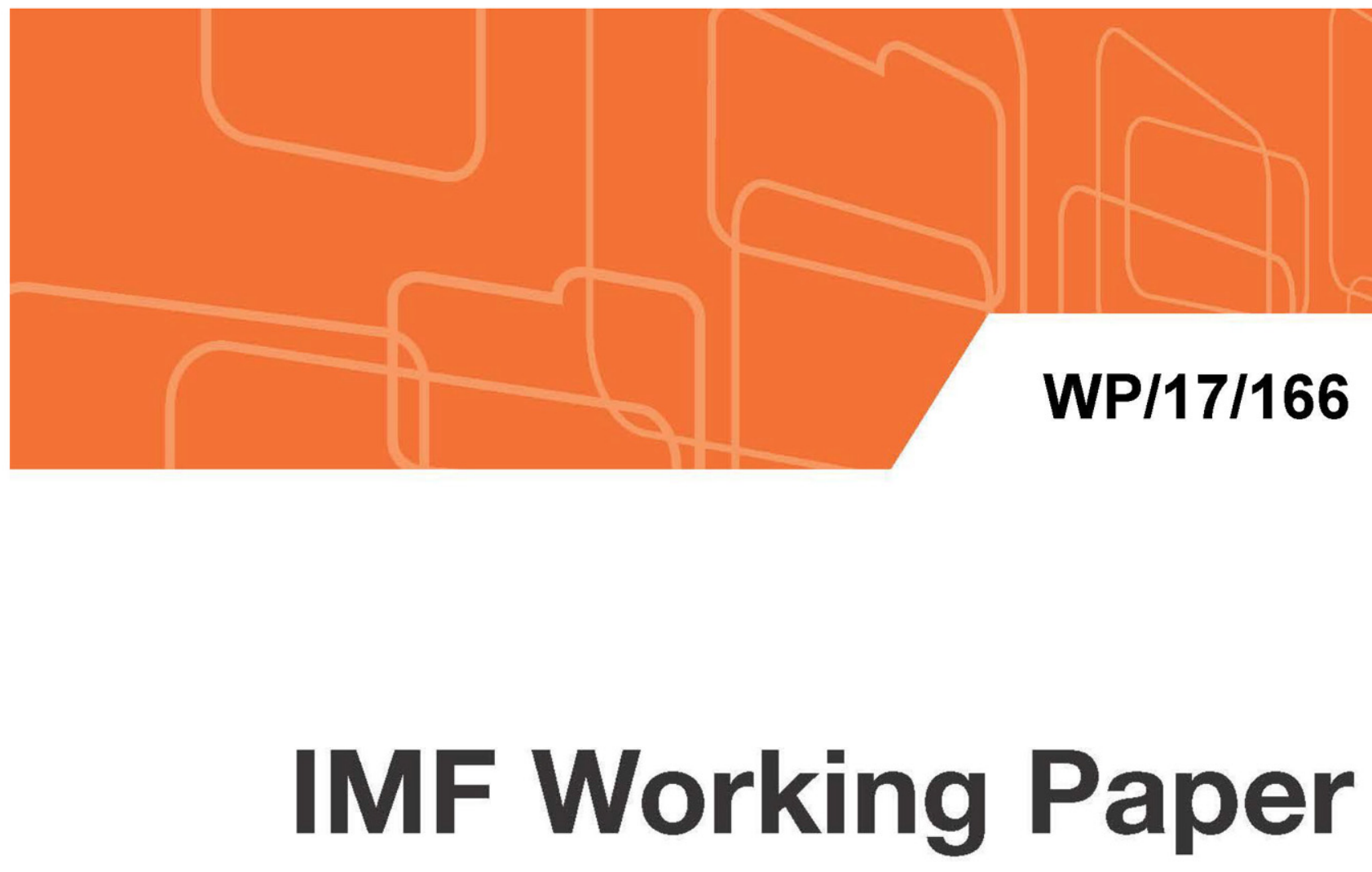

\title{
Women Are Key for Future Growth: Evidence from Canada
}

by Bengt Petersson, Rodrigo Mariscal, and Kotaro Ishi

IMF Working Papers describe research in progress by the author(s) and are published to elicit comments and to encourage debate. The views expressed in IMF Working Papers are those of the author(s) and do not necessarily represent the views of the IMF, its Executive Board, or IMF management. 


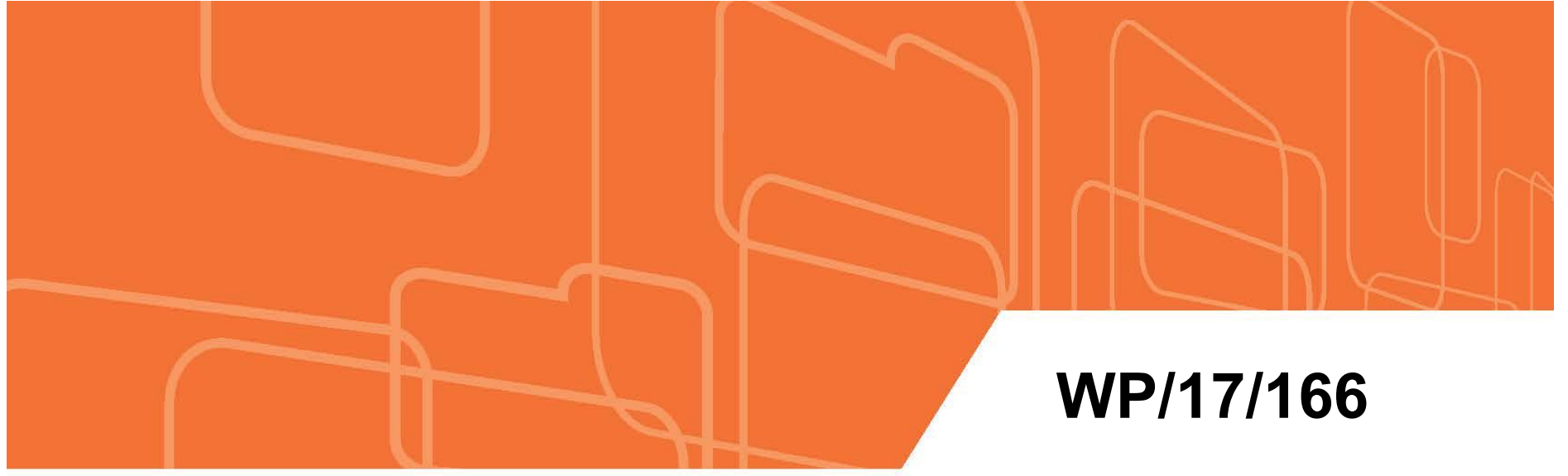

\section{IMF Working Paper}

\section{Women Are Key for Future Growth: Evidence from Canada}

by Bengt Petersson, Rodrigo Mariscal, and Kotaro Ishi

IMF Working Papers describe research in progress by the author(s) and are published to elicit comments and to encourage debate. The views expressed in IMF Working Papers are those of the author(s) and do not necessarily represent the views of the IMF, its Executive Board, or IMF management. 


\title{
IMF Working Paper
}

Western Hemisphere Department

\section{Women Are Key for Future Growth: Evidence from Canada}

Prepared by Bengt Petersson, Rodrigo Mariscal, and Kotaro Ishi'

Authorized for distribution by Cheng Hoon Lim

July 2017

\section{IMF Working Papers describe research in progress by the author(s) and are published to elicit comments and to encourage debate. The views expressed in IMF Working Papers are those of the author(s) and do not necessarily represent the views of the IMF, its Executive Board, or IMF management.}

\begin{abstract}
How important are female workers for economic growth? This paper presents empirical evidence that an increase in female labor force participation is positively associated with labor productivity growth. Using panel data for 10 Canadian provinces over 1990-2015, we found that a 1 percentage point increase in the labor force participation among women with high educational attainment would raise Canada's overall labor productivity growth by 0.2 to 0.3 percentage point a year. This suggests that if the current gap of 7 percentage points between male and female labor force participation with high educational attainment were eliminated, the level of real GDP could be about 4 percent higher today. The government has appropriately stepped up its efforts to improve gender equality, as part of its growth strategy. In particular, the government's plan to expand access to affordable child care is a positive step. However, we argue that to maximize the policy outcome given a budget constraint, provision of subsidized child care - including publicly funded child care spaces — should be better targeted to working parents.
\end{abstract}

JEL Classification Numbers: E24, H24, J13, J21, J24

Keywords: Canada, female participation, labor productivity, benefit system, taxation

Author's e-Mail Address: bengt.petersson@riksbank.se, rmariscalparedes@,imf.org, kishi@,imf.org

\footnotetext{
${ }^{1}$ The authors thank Samya Beidas-Strom, Xiangming Fang, Suhaib Kebhaj, Cheng Hoon Lim, Anna TerMartirosyan, Peter van Oudheusden, Steven Phillips, Yulia Ustyugova, Philippe Wingender, and seminar participants at the Western Hemisphere department of the IMF and at the Department of Finance Canada for valuable comments and suggestions. We also benefitted from discussion with Martha Friendly. Our gratitude goes also to Marina Primorac for her editorial assistance.
} 
ABSTRACT.

I. INTRODUCTION

II. ANALYZING WOMEN'S CONTRIBUTION TO GROWTH …...................................

A. Trends of female labor participation in Canada ....................................................

B. Empirics: female labor participation and productivity growth ............................

Empirical strategy and data

III. POLICIES TO TAP THE FULL POTENTIAL OF THE FEMALE LABOR FORCE .... $\underline{15}$

A. Where are the remaining gaps in family support policies? ..............................15

B. A case for enhancing public spending on child care ....................................

C. Tackling longstanding cultural norms to promote gender equality and increase

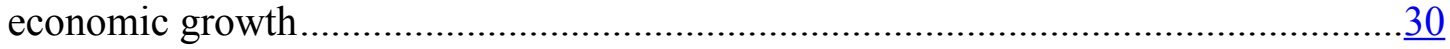

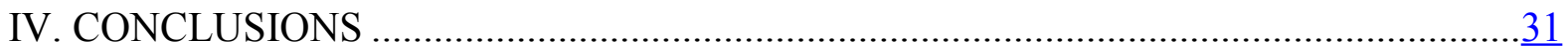

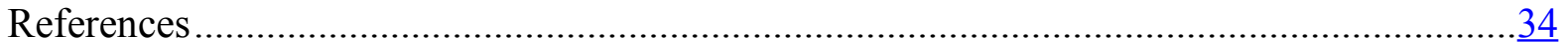

Tables

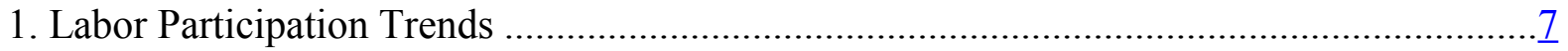

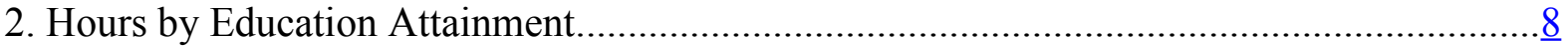

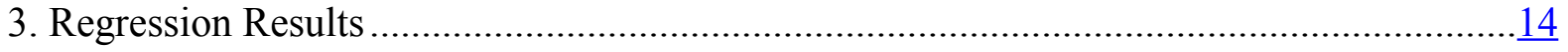

4. Canada: Calculations of Growth Impacts ................................................................. $\frac{15}{16}$

5. Population and Participation by Education Achievement ...........................................16

Figures

1. Selected Advanced Economies: Female Labor Force Participation Rate, 1976-2015.......... $\underline{5}$

2. Canada: Female Labor Force Participation Rate and Labor Productivity ........................... $\underline{5}$

3. Growth Decomposition ....................................................................................

4. Labor Productivity Growth and Female Labor Participation ........................................11

5. OECD Economies: Female Labor force Participation Rates ........................................15

6. Female Participation Rates and Tax Wedges on Secondary Earners ................................17

7. Canada: Female Labor Participation Rates and Public Spending on Early Childhood

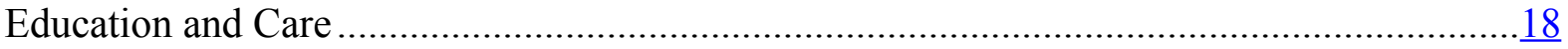

8. Advanced OECD Economies: Selected Family Policy Indicators .................................19

9. Canada: Child Care Assistance Program By Province …................................................

10. Decomposition of Marginal Effective Benefits, Today's Policy ...................................24

11. Female Labor Force Participation Rates in Quebec and Rest of Canada ........................ 25

12. Marginal Effective Benefits, No Benefits for Families with a Stay at Home Parent ........ $\underline{26}$

13. Marginal Effective Benefits, Subsidized Child Care Fees........................................... 28

14. Summary: Marginal Effective Benefits under Alternative policies...............................29

15. Percentage of Mothers and Fathers Who Take Parental Leave .................................... $\underline{30}$ 
Boxes

Box 1. The Swedish Parental Leave and Child Care System $\underline{32}$

Annexes

I. Data Description .$\underline{38}$

II. Child Benefit and Day Care Subsidy Programs by Province .......................................... $\underline{42}$

III. Canada: Illustrative Calculations of Marginal Benefit Rates by Province ....................... 46 


\section{INTRODUCTION}

“It's not just women's issues. It's all of our issues. And teaching that to our kids is really, really important. Because we know if kids grow up in a more equal world, it is a better word." —Canadian Prime Minister Justin Trudeau.

Canada has made great strides in boosting female labor participation over the past several decades. In 1976, only half of Canadian women were in the labor market, below the United States, and much lower than the Nordic economies (Figure 1). Four decades later, Canada's female labor force participation rate has increased to nearly 75 percent, a far more impressive progress than in many other advanced economies, including the United States (where the rate has actually fallen since the middle of the 1990s). As a result, the gap with the Nordic economies has almost been eliminated.

The greater inclusion of women in the economy has been an important source of growth in Canada. Between 1976 and 2015, total labor force in Canada increased by 8.8 million (or 84 percent), 5.2 million of which were women. Without women, Canada's economy would have been much smaller. In addition, the integration of women in the labor market seems to have enhanced productivity as more and more women with a post-secondary education entered the labor market. Indeed, the increase in female labor force participation especially between the mid-1990s and the mid-2000s was in tandem with an increase in labor productivity in Canada (Figure 2). Today,

Figure 1. Selected Advanced Economies: Female Labor Participation, 1976-2015 (Percent, ages 25 to 54 years old)

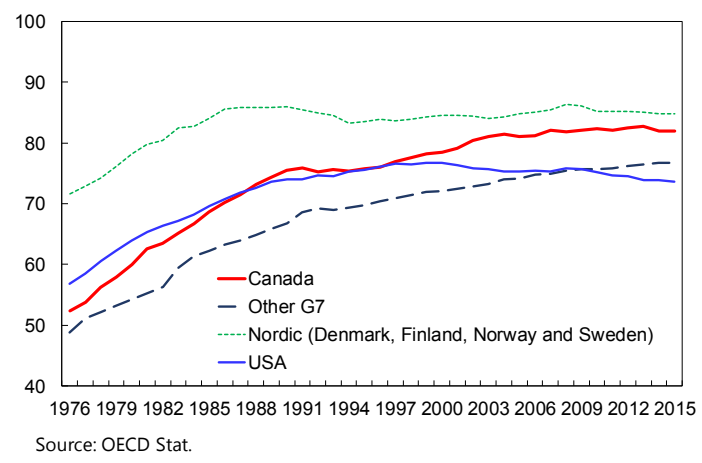

Figure 2. Canada: Female Labor Force Participation Rate and Labor Productivity

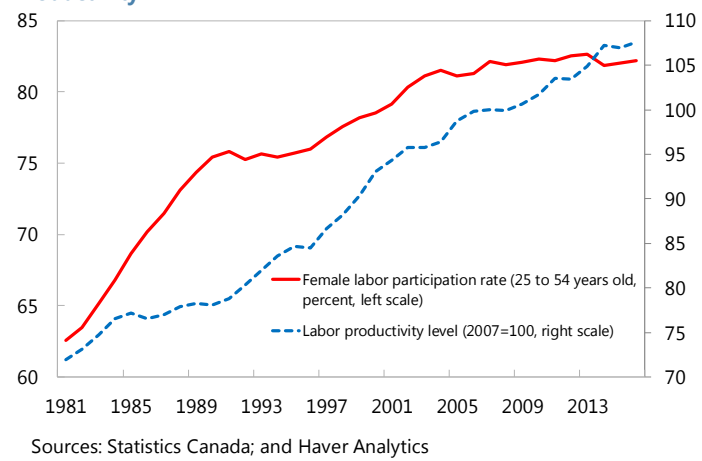
Canadian women are among the most educated in the world.

However, despite significant progress in recent decades, gender gaps remain in Canada. Female labor force participation lags male participation by about 9 percentage points. In addition, Canada's gender wage gap is well above the OECD average (OECD 2017), and progress in promoting women's representation in senior management has been slow, with women making up only one in four senior managers. Accordingly, more effort is still needed to improve gender equality and further integrate women in the labor market to lift overall economic growth.

Why is gender equality an especially important economic issue now? The Canadian economy, like other advanced economies, is expected to face growth headwinds, arising from unfavorable demographic pressure. The Bank of Canada has assessed that labor input growth could be almost halved (from 0.7 percent a year in 2015 to 0.4 percent in 2020) due to the slowdown in the growth rate of the working age population (Bank of Canada 2016). But 
female labor resources have not been fully tapped, and policy reform to bring more females to the workplace could effectively counterbalance the demographic pressure that is predicted to rise in the future.

The primary objective of this paper is to analyze the impact of female labor participation on labor productivity growth in Canada. Several studies have analyzed gender equality and growth (see, for example, IMF 2013; OECD, ILO, IMF, and World Bank 2014; and IMF 2017). However, to our knowledge, this paper is the first to explicitly quantify the impact of female labor participation on labor productivity growth using Canada as a case study. The paper is organized as follows. Section II analyzes women's contribution to growth. Section III discusses policies to tap the full potential of female labor force. Section IV concludes.

\section{AnALYZIng WOMEn's CONTRIBUTion to GrowTH}

Unless otherwise noted, our analysis focuses on the core working age group (ages 25-54) for the following reasons.

- It is sensible to conjecture that workers belonging to the core working age have the highest labor productivity potential in their life cycle, as many studies suggest (see for example, Skirbekk 2003 and Feyrer 2007).

- This age group dominates the labor force, accounting for about two-thirds of the total female labor force.

- Many people in this group have family and young children. This means that this age group must handle important decisions about work-life balance. This pressure is more acute for women, given the traditional division of labor between men and women in a family.

\section{A. Trends of female labor participation in Canada}

In Canada, over the past few decades, the growth of female labor force has constantly exceeded that of male labor force. From late 1970s to the 1980s, the female labor force of the core working-age group increased by 5-6 percent a year on average, compared with 2.2 percent for men (Table 1). The pace of female labor force expansion has since declined but has consistently surpassed male labor force growth. As a result, the gap between men and women in the labor force participation rate has narrowed from nearly 39 percentage points in the late 1970s to about 9 percentage points in the past five years. Furthermore, the number of women with full time jobs has also gradually grown: the portion of women working full time accounted for three-fourths of working women in the late 1970s and now exceeds 80 percent. 
Table 1. Canada: Labor Participation Trends

(Ages 25-54, percent, period average)

\begin{tabular}{|c|c|c|c|c|c|c|c|c|}
\hline & \multicolumn{2}{|c|}{$\begin{array}{l}\text { Growth of labor } \\
\text { force }\end{array}$} & \multicolumn{3}{|c|}{ Labor participation rate } & \multicolumn{3}{|c|}{ Full-time employment ratio } \\
\hline & Males & Females & $\begin{array}{l}\text { Males } \\
\text { (1) }\end{array}$ & $\begin{array}{c}\text { Females } \\
\text { (2) }\end{array}$ & Gap (1-2) & $\begin{array}{l}\text { Males } \\
\text { (3) }\end{array}$ & $\begin{array}{c}\text { Females } \\
\text { (4) }\end{array}$ & Gap (3-4) \\
\hline 1977-79 & 2.2 & 5.7 & 94.5 & 56.0 & 38.5 & 98.3 & 76.9 & 21.3 \\
\hline 1980-89 & 2.2 & 5.0 & 93.7 & 67.6 & 26.2 & 97.2 & 76.3 & 20.9 \\
\hline 1990-99 & 1.2 & 2.0 & 91.5 & 76.2 & 15.3 & 95.6 & 77.2 & 18.4 \\
\hline 2000-09 & 0.6 & 1.0 & 91.3 & 80.9 & 10.4 & 95.3 & 79.7 & 15.6 \\
\hline $2010-16$ & 0.2 & 0.3 & 90.7 & 82.3 & 8.5 & 94.5 & 80.7 & 13.8 \\
\hline
\end{tabular}

Source: Statistics Canada; and Haver Analytics

There has also been a gradual but an important shift in the composition of female labor force. Table 2 shows the composition of hours worked by educational attainment. The rapid increase in women's hours worked-above 40 percent growth on average per decade in the 1970 s and 1980s - was driven mainly by women with relatively lower and moderate educational attainment (namely, "primary or secondary education" and "some or completed post-secondary education"). Over time, though, women with high educational attainment ("university degrees or above") grew faster than other categories: in the 1960s, only 1.7 percent of total female labor force (measured as worked hours) had university degrees, compared with 4.8 percent for men. The share of highly educated females has since then risen steadily and faster than men, and by 2010-16, it reached about 25 percent of total female workforce, whereas for men it was only about 22 percent.

How important are these trends for boosting economic growth?

The positive labor supply effect is one important factor, which we can calculate using growth accounting. To this end, because the focus of this paper is not on capital, we decompose GDP growth into the change in hours worked (that is, the change in the number of workers multiplied by each worker's working hours) and the labor productivity growth (change in output per hours worked). Women's total hours worked increased strongly over the past 35 years: between 1990 and 2015 , the average annual growth rate was 1.7 percent, compared with men's average of 1 percent. The increase in women's total hours worked contributed to about 30 percent of overall output growth in the 1980s and was shy of 23 percent - still greater than men's - in the following two decades, as the growth of the female labor force moderated (Figure 3 ). 
Table 2. Canada: Hours Worked by Educational Attainment

(Period average)

\begin{tabular}{|c|c|c|c|c|c|c|}
\hline & $1960 \mathrm{~s}$ & 1970 s & 1980s & $1990 \mathrm{~s}$ & 2000 s & 2010-161/ \\
\hline & \multicolumn{6}{|c|}{ ('000 hours per year) } \\
\hline \multicolumn{7}{|l|}{ Females } \\
\hline Primary or secondary education & 2,392 & 2,902 & 3,405 & 3,245 & 3,211 & 2,833 \\
\hline Some or completed post-secondary education & 282 & 914 & 1,812 & 2,774 & 3,773 & 3,975 \\
\hline University degrees or above & 47 & 151 & 410 & 845 & 1,560 & 2,231 \\
\hline Female total & 2,721 & 3,967 & 5,627 & 6,863 & 8,544 & 9,039 \\
\hline \multicolumn{7}{|l|}{ Males } \\
\hline Primary or secondary education & 8,313 & 7,233 & 6,560 & 5,990 & 5,647 & 5,386 \\
\hline Some or completed post-secondary education & 930 & 2,528 & 3,876 & 4,907 & 6,350 & 6,778 \\
\hline University degrees or above & 461 & 734 & 1,200 & 1,817 & 2,676 & 3,398 \\
\hline Male total & 9,704 & 10,495 & 11,636 & 12,714 & 14,674 & 15,562 \\
\hline & \multicolumn{6}{|c|}{ (Percent change from the previous period) } \\
\hline \multirow{3}{*}{$\begin{array}{l}\text { Female total } \\
\text { Male total }\end{array}$} & $\ldots$ & 45.8 & 41.9 & 22.0 & 24.5 & 5.8 \\
\hline & $\ldots$ & 8.2 & 10.9 & 9.3 & 15.4 & 6.1 \\
\hline & \multicolumn{6}{|c|}{ (Percentage share) } \\
\hline \multicolumn{7}{|l|}{ Females } \\
\hline Primary or secondary education & 87.9 & 73.2 & 60.5 & 47.3 & 37.6 & 31.3 \\
\hline Some or completed post-secondary education & 10.4 & 23.0 & 32.2 & 40.4 & 44.2 & 44.0 \\
\hline University degrees or above & 1.7 & 3.8 & 7.3 & 12.3 & 18.3 & 24.7 \\
\hline Female total & 100.0 & 100.0 & 100.0 & 100.0 & 100.0 & 100.0 \\
\hline \multicolumn{7}{|l|}{ Males } \\
\hline Primary or secondary education & 85.7 & 68.9 & 56.4 & 47.1 & 38.5 & 34.6 \\
\hline Some or completed post-secondary education & 9.6 & 24.1 & 33.3 & 38.6 & 43.3 & 43.6 \\
\hline University degrees or above & 4.8 & 7.0 & 10.3 & 14.3 & 18.2 & 21.8 \\
\hline \multirow[t]{2}{*}{ Male total } & 100.0 & 100.0 & 100.0 & 100.0 & 100.0 & 100.0 \\
\hline & \multicolumn{6}{|c|}{ (Percentage points contributions to total hours worked growth) } \\
\hline \multicolumn{7}{|c|}{ 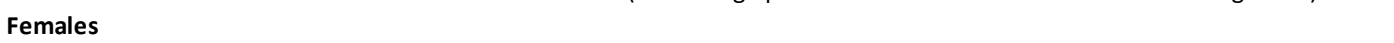 } \\
\hline Primary or secondary education & $\ldots$ & 4.1 & 3.5 & -0.9 & -0.2 & -1.6 \\
\hline Some or completed post-secondary education & $\ldots$ & 5.1 & 6.2 & 5.6 & 5.1 & 0.9 \\
\hline University degrees or above & $\ldots$ & 0.8 & 1.8 & 2.5 & 3.7 & 2.9 \\
\hline Female total & $\ldots$ & 10.0 & 11.5 & 7.2 & 8.6 & 2.1 \\
\hline \multicolumn{7}{|l|}{ Males } \\
\hline Primary or secondary education & $\ldots$ & -8.7 & -4.7 & -3.3 & -1.7 & -1.1 \\
\hline Some or completed post-secondary education & $\ldots$ & 12.9 & 9.3 & 6.0 & 7.4 & 1.8 \\
\hline University degrees or above & $\ldots$ & 2.2 & 3.2 & 3.6 & 4.4 & 3.1 \\
\hline Male total & $\ldots$ & 6.4 & 7.9 & 6.2 & 10.0 & 3.8 \\
\hline Total females and men & $\ldots$ & 16.4 & 19.4 & 13.4 & 18.6 & 6.0 \\
\hline
\end{tabular}

Sources: Statistics Canada, CANSIM Tables 383-0024 and 282-0004; and authors' estimates.

1/ CANSIM Table 383-0024 provides data only through 2010. Data beyond 2011 are based on author's estimates using CANSIM Table 282-0004.

Productivity is another factor in the influence of women's labor participation on growth. The growth of female labor participation has been increasingly driven by women with high 
educational attainment. As well discussed in the economic literature on growth, better education - and associated improvements in human capital - has been among the important determinants of labor productivity, and thus economic growth (for example, Mankiw and others 1992, Barro and Lee 1993 and 2000). How important has the productivity channel been in Canada? To answer this question, we ran productivity growth regressions, discussed in the next section.

\section{B. Empirics: female labor participation and productivity growth}

\section{Empirical strategy and data}

The goal of our empirical analysis is to find statistical relationships between female labor participation and labor productivity growth. We also attempt to find how different characteristics of female workers have contributed to labor productivity growth. To this end, we begin with examining the broadest pool of female workers, and then delve deeper into its subgroups, for example by educational attainment. The key variables used in the analysis-labor productivity and labor force participation-are calculated as follows, based on national accounts and labor force survey estimates from Statistics Canada.

- Labor productivity $(L P)$. Real GDP per total hours worked. Growth of labor productivity is calculated as the first difference of the logarithm of labor productivity.

- Female labor force participation. We examine two indicators. ${ }^{2}$

- Female labor force participation rate $\left(\frac{L^{W}}{P^{W}}\right)$, defined as the number of female labor force participants $\left(L^{W}\right)$ as a percentage of female population $\left(P^{W}\right)$. The labor force participation rate for a specific subgroup - for example, females with high educational attainment - is calculated as the number of labor force participants with a specific characteristic as a percentage of the total population with the same characteristic.

- The share of female workers with a specific characteristic - for example, the share of female workers with high educational attainment, $L^{W, H i g h}$ _in the female population is calculated as $\frac{L^{W, H i g h}}{P^{W}}{ }^{3}$

\footnotetext{
${ }^{2}$ For comparison purposes, we also calculate some comparable indicators for men.

${ }^{3}$ Note that the share of female workers with high educational attainment $\left(L^{W, H i g h}\right)$ in the female population $P^{W}$ can be decomposed into the labor participation rate $\left(L^{W, H i g h} / P^{W, H i g h}\right)$ and their population share $\left(P^{W, H i g h} / P^{W}\right)$ as follows:

$$
\frac{L^{W, H i g h}}{P^{W}}=\frac{L^{W . H i g h}}{P^{W, H i g h}} \times \frac{P^{W . H i g h}}{P^{W}}
$$
}


We use data from the 10 Canadian provinces. ${ }^{4}$ This approach has the advantage of facilitating consistent comparison across provinces over time, thus avoiding the measurement problems associated with many growth studies using large cross-country data sets.

The sample period is from 1990 to 2015. The annual data are averaged for five 5-year periods. We are interested in long-term relationships and thus want to exclude cyclical effects arising from short-run business fluctuations. The sample data set is balanced (see data description and descriptive statistics in Annex I).

Figure 4 plots statistical relationships between labor productivity growth and various measures of female labor participation for the full sample period. We observe the following:

- A positive relationship between female labor force participation rate and labor productivity growth rate (top left panel).

- Clear evidence that the participation rate for women with high educational attainment is positively correlated with labor productivity growth (top right panel).

- The share of female workers with high educational attainment seems to be positively associated with labor productivity growth, although the slope of the regression line is relatively flat (bottom left panel).

- Positive associations are more evident for female workers with both high educational attainment and full-time employment (bottom right panel).

\footnotetext{
${ }^{4}$ The 10 Canadian provinces are Alberta (AB), British Columbia (BC), Manitoba (MB), New Brunswick (NB), Nova Scotia (NS), Newfoundland and Labrador (NL), Ontario (ON), Prince Edward Island (PE), Quebec (QC), and Saskatchewan (SK).
} 
Figure 4. Labor Productivity Growth and Female Labor Participation 1/ (1990-2015 average)
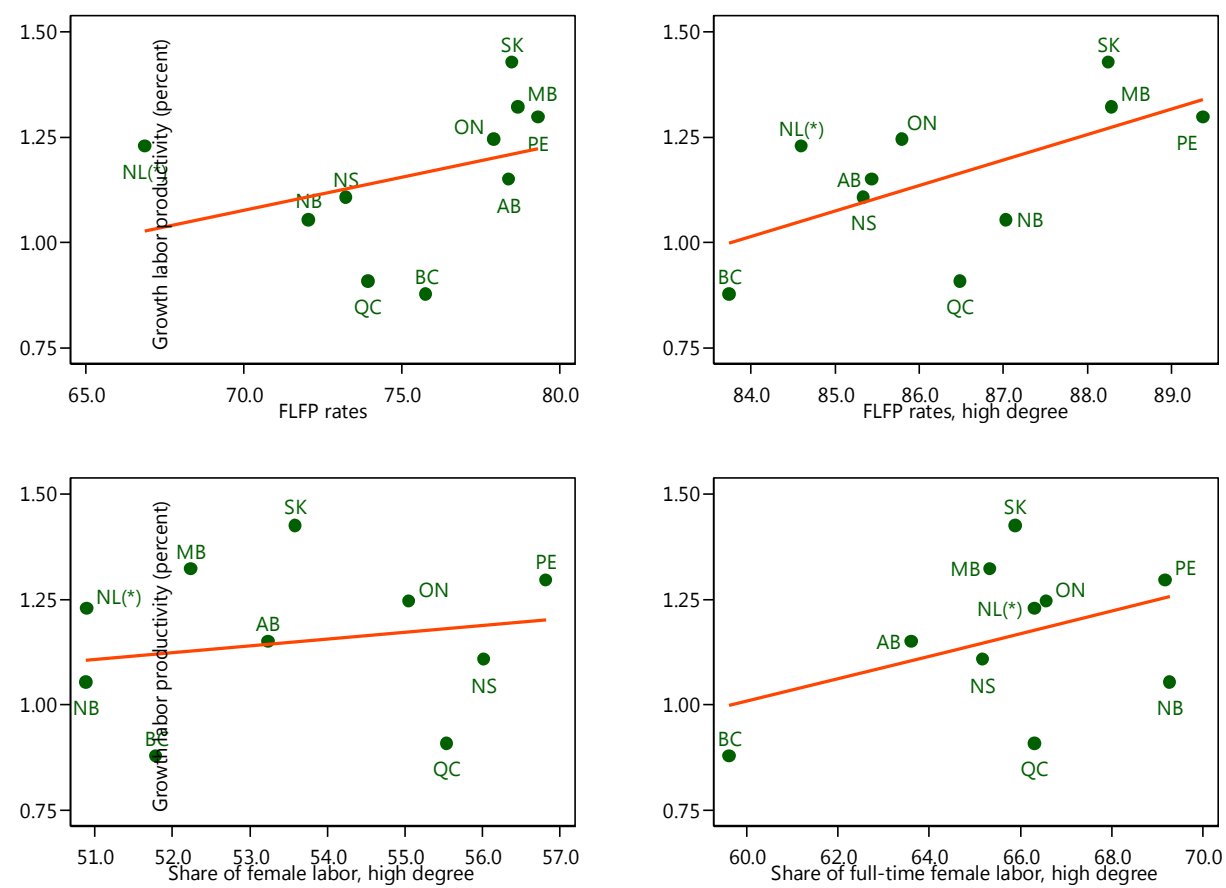

1/ For Newfoundland and Labrador (NL), an outlier outcome for 2002 is excluded. In that year, Terra Nova offshore oil field started operating, boosting oil production by 90 percent and the province's real GDP by 16 percent. With a small increase in hours worked, labor productivity grew by 16 percent in Newfoundland and Labrador in 2002.

\section{Regression model}

Following the setup used in many growth studies (for example, Barro and Lee 2001), we estimate the following model:

$$
\begin{aligned}
& \quad \Delta L P_{i t}=\alpha+\beta[\text { female labor participation variables }]_{i t}+\gamma[\text { control variables }]_{i t} \\
& +\mu_{i}+\varepsilon_{i t},
\end{aligned}
$$

where $i$ and $t$ denote province and time, respectively; $\mu_{i}$ denotes an unobserved fixed effect capturing time-invariable heterogeneity across provinces; and $\varepsilon_{i t} \sim I I D\left(o, \sigma_{\varepsilon}^{2}\right)$ is a whitenoise error term.

The dependent variable, $\Delta L P_{i t}$, is labor productivity growth. Explanatory variables are divided into female labor participation variables and a set of control variables. The control variables are those most relevant to productivity growth and following the growth literature 
include the initial level of labor productivity; ${ }^{5}$ research and development spending per hours worked; the growth rate of foreign exports and interprovincial trade; the growth rate of capital stock per hours worked; the change in net migration inflows as a percent of population; and the rule of law index (a proxy for the quality of institutions; see Annex I for data description).

We estimate the above equation using the fixed-effects model and the generalized method of moment (GMM) estimator. Among various GMM estimators, we choose the difference GMM estimator from Arellano and Bond (1991), because it addresses problems related to inconsistent estimators due to variable endogeneity and a relatively short sample period combined with a fairly large cross section data ("small T, and large N"). ${ }^{6}$ We use as instruments, lagged explanatory variables, the number of births per woman, voice and accountability index, the percentage share of female legislators, and that of female senior officials and managers. These instruments are used as proxies for a female-friendly environment, a role model effect, and expected career improvement among women.

\section{Results}

We present the main regression results in Table 3.

- Models 1 and 2 present the results of fixed-effects models. Consistent with our priors, female labor participation rates are positively and significantly correlated with labor productivity growth, with the greater contribution by females with high educational attainment.

- Models 3-9 are based on the GMM estimator. The coefficient on "all females" (which includes all types of educational attainment) turns negative and insignificant (model 3), but the coefficient on "females with high educational attainment" is still positive and highly significant. This result is robust even if we control for "males with high educational attainment" (model 5). The negative sign on the males' coefficient is surprising: it could be interpreted as a negative contribution by men to productivity. But this result may instead reflect a statistical issue: that the participation rate of highly educated men has been broadly flat at a high level for the sample period, and thus lacks meaningful variance both across time and across sections. ${ }^{7}$

\footnotetext{
5 The setup of the model assumes "convergence" of provincial productivity, following Coulombe and Lee (1995) and Lee and Coulombe (1995).

${ }^{6}$ An alternative approach would be the Blundell and Bond (1998) system GMM estimator, which is more efficient than the difference GMM estimator when both the coefficient of the lagged dependent variable and the ratio $\sigma_{\mu} / \sigma_{\varepsilon}$ is high. However, under this approach, the dependent variable has to converge to its mean (initial condition assumption), and the first difference of instrument variables must be uncorrelated with the fixed effects. Because of difficulty in finding such conditions, we did not take this approach. Moreover, Hayakawa (2009) shows that when the data are mean-nonstationary and the degree of heterogeneity is large (as in our case), the difference GMM estimator performs well.

7 The coefficient on "males with high educational attainment" was negative even if females' variable was excluded.
} 
- The positive contribution of "females with high educational attainment" to productivity growth does not appear to be persistent. Model 6 shows that the coefficient on the quadratic term of the female variable is negative, indicating diminishing marginal returns to scale-i.e., the positive contribution of the females with high educational attainment would eventually diminish after the participation increase wanes.

- "Females with low educational attainment" is also positively associated with labor productivity growth, but the coefficient is much smaller and insignificant (model 7).

- The positive association between female participation and productivity growth is particularly strong for females working full time (model 8).

- An alternative female labor force variable - the share of highly educated female labor in the female population-is also positive and highly significant (model 9).

\section{Simulations of the impact of higher female labor participation on economic growth}

The regression results permit a rough simulation of the impact of higher female labor participation on GDP. Although caution is needed when interpreting causality, the predicted impact on GDP can be calculated by estimating the direct impact due to an increase in labor input and the indirect impact through the productivity enhancing channel.

Table 4 presents the simulation result, which underscores the nontrivial contribution of the female workforce for Canada's long-term growth potential.

- For men and women with high educational attainment, the gender participation gap averaged 6.8 percent percentage points in 2010-15. This implies that if the gender gap were to be closed, the number of female workers would be raised by 0.3 million, equivalent to 1.8 percent of total labor force (including both men and women with all levels of educational attainment at all ages).

- We use model 4 to calculate the impact on productivity. ${ }^{8}$ The estimated coefficient is 0.317 (with the standard error of 0.149). Assuming that the participation rate of females with high educational attainment increases by 6.8 percent percentage points to close the gender gap, labor productivity growth would be higher by 2.2 percentage points (with \pm one standard error band (68 percent significance) of 1.2-3.2 percentage points).

- Adding the two effects, the level GDP would be higher by 4 percent (with \pm one standard error band (68 percent significance) of 3-5 percent).

\footnotetext{
${ }^{8}$ Note that p-value of the Sargan test — the null hypothesis is "joint validity of the full instrument set"-for model 4 is 0.046 , which is not very high and thus raises concern about model validity. Note that model 5 (which has a high $p$ value, 0.161 ) shows a slightly higher estimated coefficient, 0.404 . Accordingly, we felt that 0.317 in model 4 might be underestimated, but we selected the conservative number for the simulation.
} 
Table 3. Canada: Regression Results

Dependent variable: labor productivity growth

\begin{tabular}{|c|c|c|c|c|c|c|c|c|c|}
\hline \multirow[t]{2}{*}{ Estimation method } & \multicolumn{2}{|c|}{$\begin{array}{l}\text { OLS (fixed effects and } \\
\text { instrumental variables) }\end{array}$} & \multicolumn{7}{|c|}{ Arellano-Bond GMM 1/ } \\
\hline & Model 1 & Model 2 & Model 3 & Model 4 & Model 5 & Model 6 & Model 7 & Model 8 & Model 9 \\
\hline Level of labor productivity (t-1) & $\begin{array}{c}-10.460 * * * \\
(1.500)\end{array}$ & $\begin{array}{c}-10.87^{* * *} \\
(2.244)\end{array}$ & $\begin{array}{c}-9.188 * * * \\
(1.996)\end{array}$ & $\begin{array}{c}-13.250^{* * *} \\
(2.414)\end{array}$ & $\begin{array}{c}-9.131^{* * *} \\
(3.051)\end{array}$ & $\begin{array}{c}-12.36 * * * \\
(2.674)\end{array}$ & $\begin{array}{c}-10.134 * * * \\
(2.996)\end{array}$ & $\begin{array}{c}-16.689 * * * \\
(2.834)\end{array}$ & $\begin{array}{c}-17.121 * * * \\
(2.780)\end{array}$ \\
\hline$R \& D$ stock per hour worked (t-1) & $\begin{array}{c}1.238 \\
(1.032)\end{array}$ & $\begin{array}{c}1.518 \\
(1.231)\end{array}$ & $\begin{array}{l}1.887^{* *} \\
(0.961)\end{array}$ & $\begin{array}{c}1.513 \\
(1.300)\end{array}$ & $\begin{array}{l}1.754+ \\
(1.113)\end{array}$ & $\begin{array}{l}1.832+ \\
(1.212)\end{array}$ & $\begin{array}{c}1.666 \\
(1.317)\end{array}$ & $\begin{array}{c}1.430 \\
(1.443)\end{array}$ & $\begin{array}{l}-1.209 \\
(1.543)\end{array}$ \\
\hline Growth of external exports & $\begin{array}{l}0.030 \\
-0.037\end{array}$ & $\begin{array}{c}0.0335 \\
(0.0361)\end{array}$ & $\begin{array}{c}0.009 \\
(0.044)\end{array}$ & $\begin{array}{c}0.017 \\
(0.033)\end{array}$ & $\begin{array}{c}0.000 \\
(0.040)\end{array}$ & $\begin{array}{c}0.0204 \\
(0.0313)\end{array}$ & $\begin{array}{c}0.001 \\
(0.052)\end{array}$ & $\begin{array}{c}0.042 \\
(0.032)\end{array}$ & $\begin{array}{l}-0.007 \\
(0.034)\end{array}$ \\
\hline Growth of intra-provincial trade & $\begin{array}{c}0.089 * * * \\
(0.022)\end{array}$ & $\begin{array}{l}0.107 * * * \\
(0.0185)\end{array}$ & $\begin{array}{c}0.097^{* * *} \\
(0.026)\end{array}$ & $\begin{array}{c}0.104^{* * *} \\
(0.020)\end{array}$ & $\begin{array}{c}0.119 * * * \\
(0.031)\end{array}$ & $\begin{array}{c}0.105^{* * *} \\
(0.0173)\end{array}$ & $\begin{array}{c}0.101^{* * *} \\
(0.031)\end{array}$ & $\begin{array}{c}0.103 * * * \\
(0.021)\end{array}$ & $\begin{array}{c}0.078^{* * *} \\
(0.019)\end{array}$ \\
\hline Index of rule of law & $\begin{array}{c}2.776^{* * *} \\
(0.982)\end{array}$ & $\begin{array}{c}2.718^{* *} \\
(1.243)\end{array}$ & $\begin{array}{c}3.879 * * * \\
(1.230)\end{array}$ & $\begin{array}{c}4.067^{* * *} \\
(1.523)\end{array}$ & $\begin{array}{l}-2.864 \\
(3.142)\end{array}$ & $\begin{array}{c}3.866^{* * *} \\
(1.501)\end{array}$ & $\begin{array}{l}3.091^{*} \\
(1.691)\end{array}$ & $\begin{array}{l}3.684^{*} \\
(2.184)\end{array}$ & $\begin{array}{l}-2.831 \\
(2.966)\end{array}$ \\
\hline Growth of capital stock per hour worked & $\begin{array}{c}0.299 * * * \\
(0.098)\end{array}$ & $\begin{array}{c}0.295^{* *} \\
(0.119)\end{array}$ & $\begin{array}{c}0.490^{* * *} \\
(0.073)\end{array}$ & $\begin{array}{l}0.274^{*} \\
(0.141)\end{array}$ & $\begin{array}{c}0.199 * * * \\
(0.072)\end{array}$ & $\begin{array}{c}0.300^{* * *} \\
(0.116)\end{array}$ & $\begin{array}{c}0.212^{* *} \\
(0.102)\end{array}$ & $\begin{array}{c}0.217 \\
(0.172)\end{array}$ & $\begin{array}{c}0.073 \\
(0.175)\end{array}$ \\
\hline Change in net-migration flows to population & $\begin{array}{l}1.945+ \\
(1.345)\end{array}$ & $\begin{array}{c}2.275 \\
(2.141)\end{array}$ & $\begin{array}{c}2.324^{* *} \\
(0.992)\end{array}$ & $\begin{array}{l}1.820 \\
(2.364)\end{array}$ & $\begin{array}{c}0.672 \\
(2.228)\end{array}$ & $\begin{array}{c}1.777 \\
(1.987)\end{array}$ & $\begin{array}{c}1.020 \\
(2.102)\end{array}$ & $\begin{array}{c}2.264 \\
(2.384)\end{array}$ & $\begin{array}{c}2.294 \\
(2.223)\end{array}$ \\
\hline \multicolumn{10}{|l|}{$\begin{array}{l}\text { Labor force participation rate } \\
\text { (unless otherwise indicated) }\end{array}$} \\
\hline All females & $\begin{array}{l}0.110^{*} \\
(0.066)\end{array}$ & & $\begin{array}{c}-0.036 \\
(0.053)\end{array}$ & & & & & & \\
\hline Females with high education attainment & & $\begin{array}{l}0.275^{*} \\
(0.153)\end{array}$ & & $\begin{array}{c}0.317^{* *} \\
(0.149)\end{array}$ & $\begin{array}{c}0.404 * * * \\
(0.129)\end{array}$ & $\begin{array}{l}7.534^{*} \\
(4.027)\end{array}$ & & & \\
\hline Males with high education attainment & & & & & $\begin{array}{c}-0.695^{* *} \\
(0.297)\end{array}$ & & & & \\
\hline Females with high education attainment ${ }^{\wedge} 2$ & & & & & & $\begin{array}{l}-0.0422^{*} \\
(0.0236)\end{array}$ & & & \\
\hline Females with low education attainment & & & & & & & $\begin{array}{c}0.027 \\
(0.086)\end{array}$ & & \\
\hline $\begin{array}{l}\text { Full-time females with high education } \\
\text { attainment }\end{array}$ & & & & & & & & $\begin{array}{l}0.272 * * \\
(0.109)\end{array}$ & \\
\hline $\begin{array}{l}\text { Share of highly educated female labor force in } \\
\text { female population }\end{array}$ & & & & & & & & & $\begin{array}{c}0.239 * * * \\
(0.056)\end{array}$ \\
\hline \multicolumn{10}{|l|}{ Memorandum items: } \\
\hline Number of observations & 60 & 50 & 60 & 40 & 40 & 40 & 40 & 40 & 40 \\
\hline Number of provinces & 10 & 10 & 10 & 10 & 10 & 10 & 10 & 10 & 10 \\
\hline R-squared & 0.58 & 0.49 & & & & & & & \\
\hline Hansen $\mathrm{j}$-statistics & 0.043 & 0.016 & & & & & & & \\
\hline$A R(1) p$-value & & & 0.023 & 0.046 & 0.085 & 0.026 & 0.056 & 0.093 & 0.361 \\
\hline$A R(2) p$-value & & & 0.562 & 0.577 & 0.305 & 0.601 & 0.458 & 0.401 & 0.278 \\
\hline Sargan $p$-value & & & 0.005 & 0.045 & 0.161 & 0.047 & 0.038 & 0.094 & 0.078 \\
\hline
\end{tabular}

1/ GMM specifications. As instruments, lagged explanatory variables, "fertility rates," "voice and accountability index," and "share of female legislators, senior officials and managers," are used for instrumenting female labor force variables. Robust standard errors are in parentheses, with $* * *$ indicating significance level at 1 percent, ** at 5 percent, * at 10 percent, and +15 percent. 


\begin{tabular}{|c|c|c|c|}
\hline \multicolumn{4}{|c|}{ Table 4. Canada: Calculations of Growth Impacts } \\
\hline Gender participation gap, high education & \multicolumn{3}{|c|}{ 2010-15 average } \\
\hline Males & & & 93.7 \\
\hline Females & & & 86.8 \\
\hline Gap & & & 6.8 \\
\hline \multicolumn{4}{|l|}{ Simulations } \\
\hline \multicolumn{4}{|l|}{ If the high education gender participation gap is closed, } \\
\hline The number of female labor force would be higher by: & & \multicolumn{2}{|c|}{ 2010-15 average } \\
\hline In millions & & \multicolumn{2}{|c|}{0.3} \\
\hline In percent of total labor force $\left({ }^{*}\right)$ & & \multicolumn{2}{|r|}{1.8} \\
\hline \multicolumn{4}{|l|}{ Labor productivity growth would be higher by: } \\
\hline & \multicolumn{3}{|c|}{ \pm one stand. error. confidence band } \\
\hline & Minus one SE & $\beta$ & Plus one SE \\
\hline Estimated coefficient & 0.17 & 0.32 & 0.47 \\
\hline Estimated coefficient ${ }^{*}$ gender gap $\left({ }^{* *}\right)$ & 1.2 & 2.2 & 3.2 \\
\hline Total impacts $(*+* *)$ & 3.0 & 4.0 & 5.0 \\
\hline
\end{tabular}

\section{Policies to Tap the Full Potential of the Female Labor Force}

\section{A. Where are the remaining gaps in family support policies?}

Despite significant progress in recent decades, gender gaps remain in Canada. The labor force participation rate for all women stands at 82 percent, about 10 percentage points lower than the men's rate. And internationally, although Canada's female participation rate is above the OECD average of 72 percent (age 25-54), it is below that of all the Nordic countries, including Sweden at 88 percent (Figure 5).

Stronger educational attainment among women has not resulted in a fully corresponding increase in their participation in the labor force. Although 35 percent of women have a university degree (up from 14 percent in 1990; see Table 5), compared with 29 percent of men, the labor force participation rate of these highly educated women remains at around 87 percent, below the 94 percent participation rate of men with the same education level.

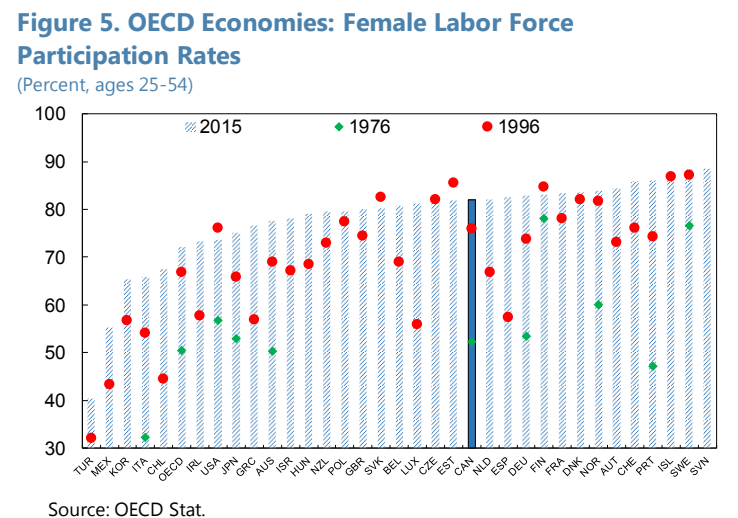

Figure 5. OECD Economies: Female Labor Force 


\begin{tabular}{|c|c|c|c|c|c|}
\hline \multicolumn{6}{|c|}{$\begin{array}{l}\text { Table 5. Canada: Population and Participation by Education Achievement } \\
\qquad \text { (Ages 25-54 years old, percent) }\end{array}$} \\
\hline & $1990 \mathrm{~s}$ & $2000 \mathrm{~s}$ & 2010-15 & \multirow[t]{2}{*}{1990} & \multirow[t]{2}{*}{2015} \\
\hline & \multicolumn{3}{|c|}{ Average } & & \\
\hline \multicolumn{6}{|l|}{ Females } \\
\hline Total population & 100.0 & 100.0 & 100.0 & 100.0 & 100.0 \\
\hline 0 to 8 years & 6.4 & 3.1 & 1.9 & 8.6 & 1.6 \\
\hline Some high school & 14.3 & 8.4 & 5.6 & 17.5 & 4.9 \\
\hline High school graduate & 23.8 & 20.8 & 17.9 & 25.4 & 17.0 \\
\hline Some postsecondary & 8.3 & 7.3 & 5.3 & 8.2 & 4.4 \\
\hline Postsecondary certificate or diploma & 30.5 & 35.9 & 37.2 & 26.6 & 37.0 \\
\hline University degree & 16.7 & 24.6 & 32.1 & 13.7 & 35.1 \\
\hline Labor force participation rates & 76.2 & 80.9 & 82.3 & 75.5 & 82.0 \\
\hline 0 to 8 years & 46.4 & 47.6 & 44.1 & 49.1 & 43.9 \\
\hline Some high school & 62.3 & 64.8 & 61.7 & 64.9 & 58.3 \\
\hline High school graduate & 75.8 & 78.1 & 76.5 & 76.1 & 74.2 \\
\hline Some postsecondary & 77.3 & 78.3 & 76.8 & 77.9 & 74.9 \\
\hline Postsecondary certificate or diploma & 83.2 & 85.8 & 86.5 & 83.8 & 86.3 \\
\hline University degree & 86.9 & 86.6 & 87.2 & 86.7 & 87.2 \\
\hline \multicolumn{6}{|l|}{ Males } \\
\hline Total population & 100.0 & 100.0 & 100.0 & 100.0 & 100.0 \\
\hline 0 to 8 years & 6.7 & 3.5 & 2.4 & 9.0 & 1.9 \\
\hline Some high school & 15.5 & 10.7 & 8.2 & 18.0 & 7.1 \\
\hline High school graduate & 20.1 & 19.7 & 20.0 & 20.0 & 20.0 \\
\hline Some postsecondary & 7.9 & 7.3 & 5.8 & 8.1 & 5.0 \\
\hline Postsecondary certificate or diploma & 30.8 & 35.6 & 36.9 & 27.8 & 37.4 \\
\hline University degree & 19.0 & 23.2 & 26.8 & 17.1 & 28.6 \\
\hline Labor force participation rates & 91.4 & 91.3 & 90.7 & 93.1 & 90.9 \\
\hline 0 to 8 years & 73.6 & 69.7 & 68.9 & 79.7 & 64.9 \\
\hline Some high school & 87.2 & 84.3 & 80.7 & 90.5 & 79.2 \\
\hline High school graduate & 92.9 & 91.4 & 89.1 & 95.2 & 88.2 \\
\hline Some postsecondary & 90.2 & 88.4 & 86.3 & 92.9 & 86.6 \\
\hline Postsecondary certificate or diploma & 94.4 & 94.2 & 93.6 & 95.7 & 93.9 \\
\hline University degree & 95.3 & 94.0 & 93.8 & 96.3 & 94.2 \\
\hline \multicolumn{6}{|l|}{ Participation gaps (males minus females) } \\
\hline Postsecondary certificate or diploma & 11.3 & 8.4 & 7.1 & 11.9 & 7.6 \\
\hline University degree & 8.3 & 7.3 & 6.6 & 9.6 & 7.0 \\
\hline
\end{tabular}


All these data suggest an opportunity to fully tap underutilized female labor sources to solve the longer-term growth concern. But this means incentives for female integration in economic activity must improve in some areas.

Many studies suggest that economic incentives play an important role in encouraging women to participate in the labor market (for example, Jaumotte 2003, Tsounta 2006, and Thévenon and Solaz 2013). These studies highlight key labor market policies that influence female labor participation: (i) tax incentives for women to work; (ii) child-related leave entitlements; and (iii) child care services. Figure 8 presents the cross-country comparison of these policies.

Our assessments of work incentives in Canada are as follows:

- Tax policies. For women who are "secondary earners" in households (often wives who earn less than their husbands), their decision to get a job, for example, depends on how much total additional tax the woman and her spouse are required to pay. In the late 1980s, the federal tax reform in Canada eliminated the elements of the tax code that created incentives similar to those provided by a system of joint taxation. Under the previous tax system the connection between a secondary earner's effective marginal tax rate and her spouse's marginal tax rate distorted the labor supply of women. ${ }^{9}$ In the 1990s, with an improved fiscal positon, the federal government actively implemented tax reforms, including tax cuts specifically focusing on families with children, further lowering tax wedges on secondary earners. This has contributed to reducing the tax wedge for the secondary earner from about 35 percent in the early 1990s to 32 percent today (Figure 6). ${ }^{10}$ These tax cuts proved successful in raising the participation of women in the workplace (Tsounta 2006; Crossley 2006; Bibbee, 2008). However, by international comparisons, the tax wedge in Canada is still relatively high, above the median of the advanced OECD economies, and thus there is potential to further reduce the tax wedge on secondary earners (Figure 8, top panel).

\footnotetext{
9 The 1988 Canadian tax reform replaced a spousal exemption (tax deduction) with a nonrefundable tax credit. Before the tax reform, the amount of tax deduction that could be claimed by the primary earner (who has a higher income and marginal tax rate - in most cases, the husband) was dependent on the secondary earner's (the wife's) income. In other words, when a married woman entered the labor market, the family's tax payments rose equally to her husband's marginal tax rate. After the reform, with the tax credit, this was no longer the case. This significantly reduced the "first dollar" marginal tax rate of women married to high-income husbands and had significant positive effects on these women's labor force participation (Crossley 2006).

${ }^{10}$ See Annex 1 for the calculation of the tax wedge on the secondary earner.
} 
- Maternity and parental leave. All OECD economies except the United States offer paid maternity and parental leaves of at least three months (Figure 8, second and third panels). In Canada, federal and provincial governments launched initiatives in the late 1990s to support parenting and early childhood development. One of the key reform measures was the lengthening of maternity and parental leaves from a maximum of 37 weeks to a maximum of 52 weeks in 2001. After having a baby, a mother can typically take 17 weeks leave from her job (the leave provisions vary across provinces, between 15 and 18 weeks), and thereafter, both parents have the option of taking leave for another 35 weeks. Thus, if a household decides that the mother would take all the parental leave herself, the total time off work can add to up to 52 weeks, compared with the advanced OECD economies' median of 41 weeks. Public spending on maternity and parental leave in Canada $^{11}$ is also higher than the median of these OECD economies.

- Early childhood education and child care policies. Canada performs poorly in this area compared with other OECD economies. Despite the strengthening of child benefits in the late 1990s and of the national early learning and child care system in the 2000sas part of parenting policy reforms, (Figure 7) Canada still—on average across all provinces - still spends relatively little on early childhood education and child care compared with other advanced economies: only US\$82 per child in

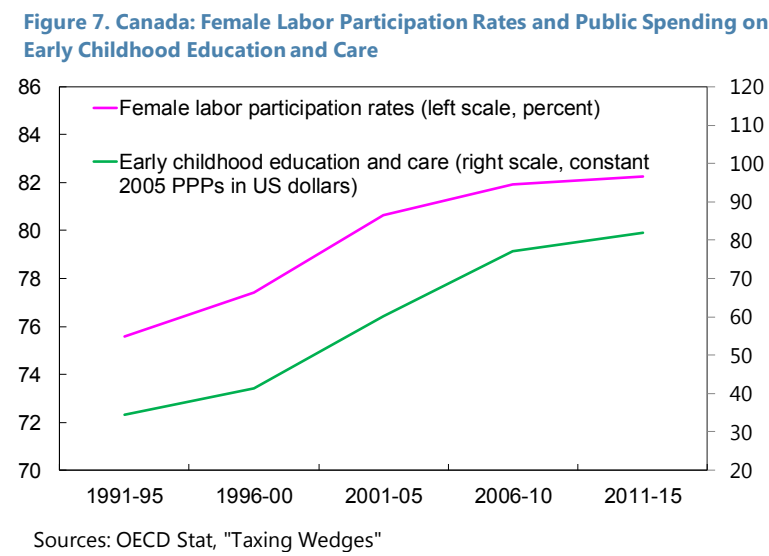
2015 (or 0.2 percent of GDP, including in cash and in kind), the lowest among OECD economies (Figure 8, bottom panel). ${ }^{12}$

\footnotetext{
${ }^{11}$ For most people, the basic rate for calculating parental benefits is 55 percent of average insurable weekly earnings, up to a maximum amount (as of January 1, 2017, the maximum yearly insurable earnings amount is $\$ 51,300)$.

${ }^{12}$ This does not include the impact of the new measures in the federal government's 2016 and 2017 budgets. The 2016 budget allocated $\$ 500$ million for early learning and child care in FY2017/18. The 2017 budget has proposed additional $\$ 7$ billion over 10 years to provinces/territories with the aim of creating 40,000 affordable child care spaces for low- and modest-income families across the country.
} 
Figure 8. Advanced OECD Economies: Selected Family Policy Indicators 1/

(Most recently available year)

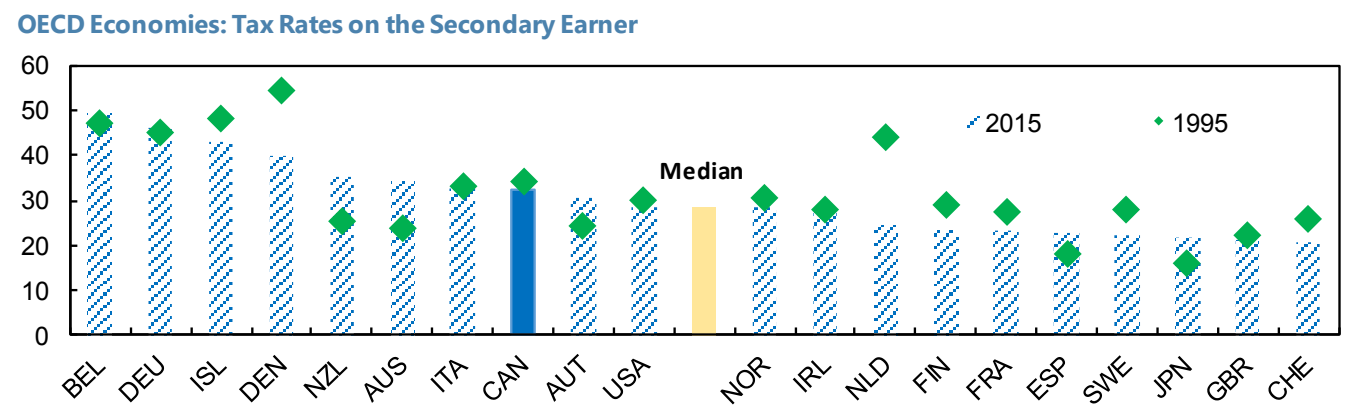

OECD Economies: Length of Paid Maternity and Parental Leave Available (Weeks)

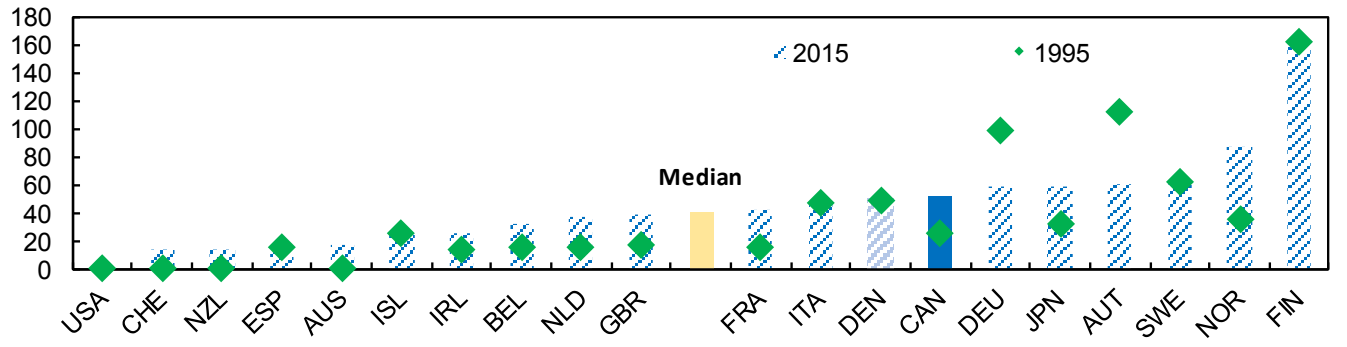

OECD Economies: Public Spending on Maternity and Parental Leave

(Per head, at constant prices (2005) and constant PPPs (2005), in US dollars)

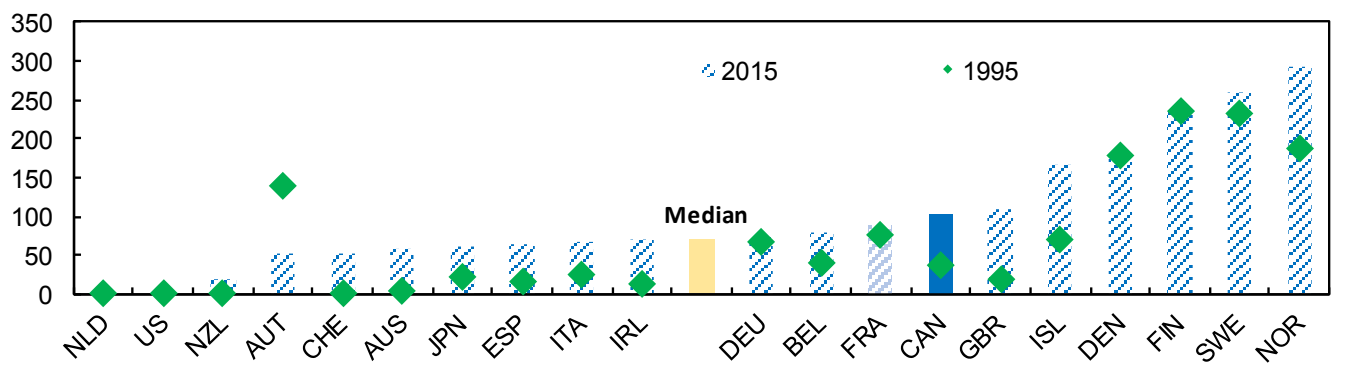

OECD Economies: Public Spending on Early Childhood Education and Care

(Per head, at constant prices (2005) and constant PPPs (2005), in US dollars)

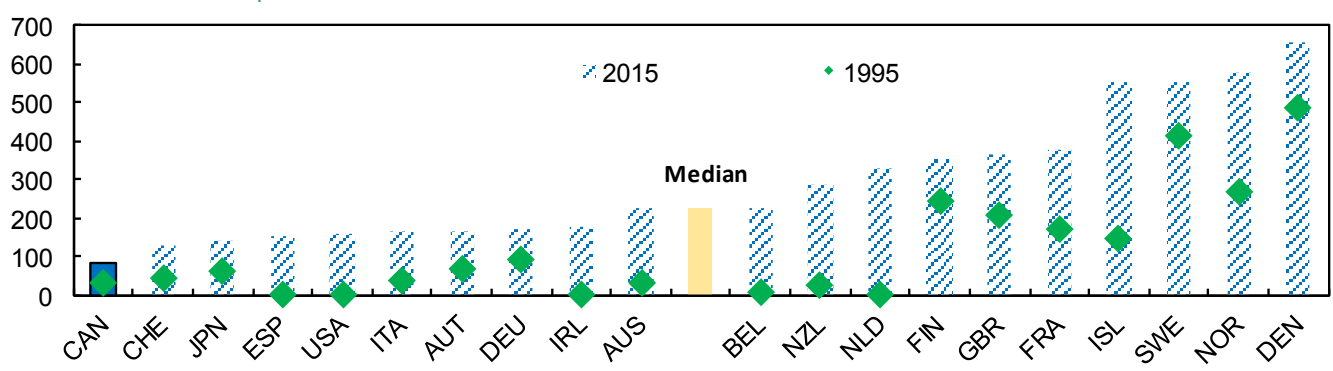

Source: OECD Stat, "Family Database," and "Tax Wedges," and World Bank World Development Indicators

$1 /$ The sample is 20 advanced OECD economies. See Annex 1 for the definition of the indicators. 
To sum up, Canada's public family support policies are mixed in terms of incentives to work. Public spending on maternity and parental leave, as well as the length of paid maternity and parental leave, are generous in Canada compared with other OECD countries. However, despite past efforts, the estimated tax wedge for the secondary earner is higher than that of most OECD peers, and public spending on early education and child care falls well short of that in many advanced economies. In the following section, we review Canada's public child care assistance programs and assess their affordability, which many studies describe as one of the highest hurdles for women to participate in the labor force (OECD, ILO, IMF, and World Bank 2015).

\section{B. A case for enhancing public spending on child care}

\section{Governments' child care and child support programs in Canada}

In the Canadian federation, child care services are within provincial jurisdiction. However, like other programs under provincial jurisdiction such as health care, the federal government may play both a policy and funding role. ${ }^{13}$ Historically, the federal government has played a relatively limited role in child care. ${ }^{14}$ Measures have included transferring non-earmarked funds through the Canada Social Transfer which provinces may choose to use for child care. The federal government also allows for a tax deduction for employment-related child care expenses (the Child Care Expense Deduction).

The federal government provides the Canada Child Benefit Program. ${ }^{15}$ This programintended to improve the financial situation of low- and medium-income families with children - adds up to a maximum annual benefit of Can $\$ 6,400$ per child under age six and Can $\$ 5,400$ per child through age 17 . Families with incomes of less than Can $\$ 30,000$ receive the maximum amount, and the benefit is reduced as family income increases.

At the provincial level, most provincial government have their own child care service provision and funding program. The programs vary in type-from simple "top-ups" to the equivalent of the federal's Canada Child Benefit Program and various stand-alone child benefit and daycare financial assistance programs - and in generosity and scope. Each province has different objectives in designing early childhood education and child care programs. The financial support instruments-for example, fee subsidies to child care providers versus income subsidies to parents with children - and provincial policymakers use them vary considerably (Figure 9 and Annex II).

\footnotetext{
${ }^{13}$ We use the term childcare broadly to include a range of services and benefits that flow to children, such as daycare programs, cash benefits to families with children, as well as specific tax reductions targeted to help families with children. We also use the term daycare, which is a formal paid arrangement whereby (usually preschool) children are cared for and participate in age-appropriate educational activities while parents work or study (see Sarlo 2006).

${ }^{14}$ In its 2015 election platform and in the 2016 and 2017 federal budgets, the federal government indicated that it would further support childcare by developing a national policy framework with provinces/territories and by providing them with federal funds.

${ }^{15}$ The Canada Child Benefit Program was introduced in July 2016, replacing the Canada Child Tax Benefit and the Universal Child Care Benefit.
} 
Panel Figure 9. Canada: Child Care Assistance Programs By Province
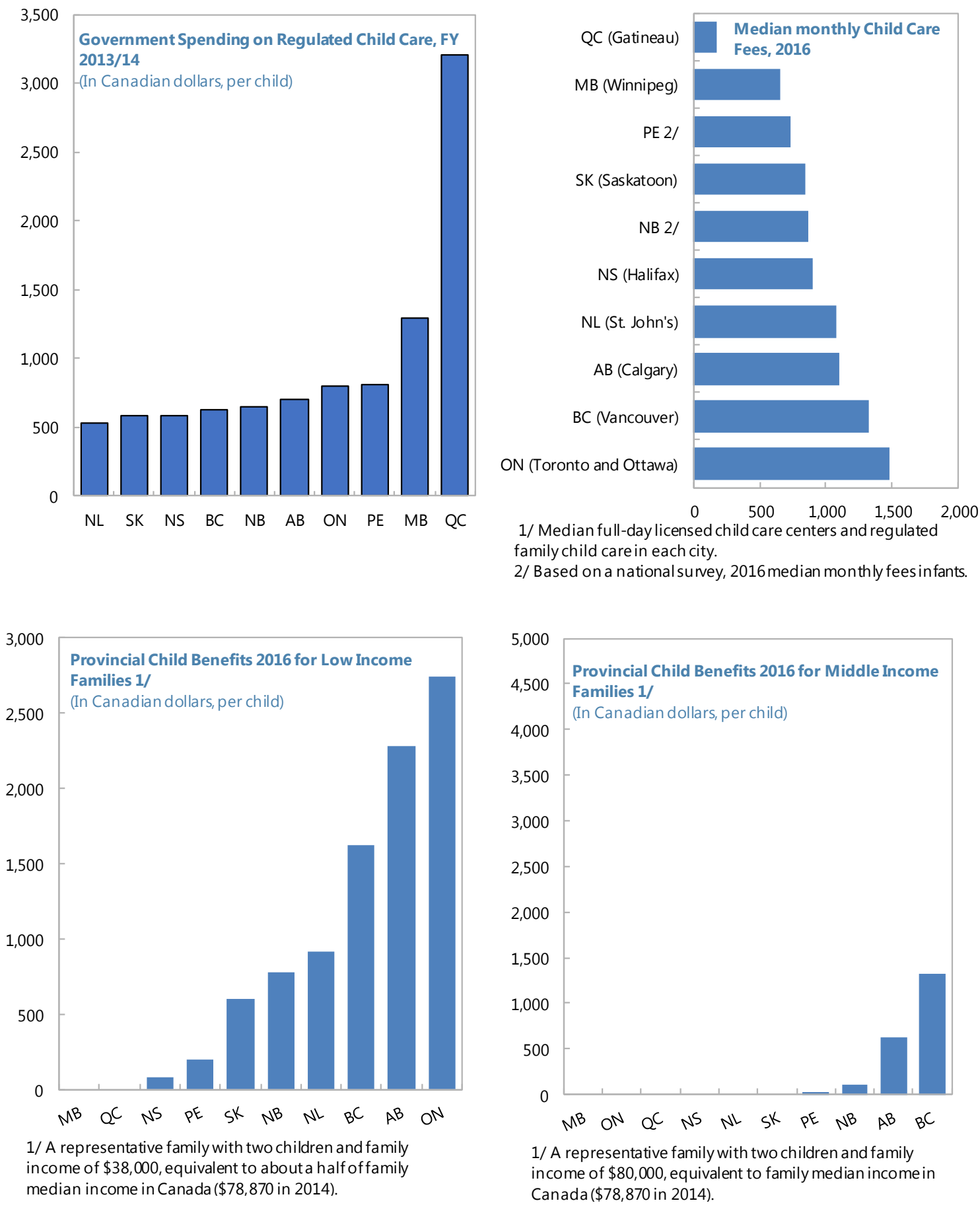

$1 /$ A representative family with two children and family income of $\$ 38,000$, equivalent to about a half of family median income in Canada $(\$ 78,870$ in 2014). Canada $(\$ 78,870$ in 2014).

Source: Macdonald D., and Friendly, M., 2016, "A Growing Concern, 2016 Child Care Fees in Canada's Big Cities", Friendly, M., B. Grady, L. Macdonald, and B. Forer, 2015, "Early Childhood Education and Care in Canada 2014;" and Canada Revenue Agency Child and Family Benefits Calculator. 
Quebec's program stands out. Of Canada's 10 provinces, Quebec, Manitoba, and Prince Edward Island cap child care fees, and these provincial governments provide more substantial financial assistance than other provinces to child care providers to compensate part of their operating costs, including wages. Of these three, Quebec provides the most generous public support. For example, the basic parent fee for regulated child care centers is set at only Can\$8.25 a day if the family's income is Can\$50,545 or less (as of end-2016). ${ }^{16}$ This is equivalent to about Can\$171 a month, much lower than the fees of about Can\$4501,400 a month charged elsewhere in the country. We analyze below how child care fees and other variables affect work incentives. ${ }^{17}$

\section{Analytical framework}

To evaluate how the tax and benefit system affects work incentives, we estimate the marginal effective benefit in each province. When deciding whether or not to get a job, one of the considerations that a couple with children makes is whether additional family income that the mother earns would pay off the costs of child care. While she stays at home, the couple need not send their children to a child care center. However, once the mother starts working, unless they have somebody (such as other relatives) to take care of their child or children free of charge, the couple must leave the children at a child care center and pay fees. The mother also needs to pay income taxes, and the family might lose some benefits as a result of its higher income. We define the marginal benefit index of work as the following:

$$
\begin{gathered}
\text { Marginal Effective Benefit Index } \\
=\frac{(\text { Houshold Net Income })_{D}-(\text { Household Net Income })_{S}}{(\text { Houshold Gross Income })_{D}-(\text { Household Gross Income })_{S}}
\end{gathered}
$$

where $D$ denotes the household consisting of two working parents (we assume here a married couple) and two children, and $S$ denotes the household, consisting of a married couple and two children with only one parent working. Gross income is taxable income, while net income is calculated as:

$$
\begin{aligned}
\text { Net Income }= & \text { Gross Income }- \text { Income Taxes Paid }- \text { Child Care Costs } \\
& + \text { Child Care Benefits }
\end{aligned}
$$

Child benefits for each province are calculated using Canada Revenue Agency's Child and Family Benefits Calculator and income tax effects, using a calculator provided by $P W C .{ }^{18}$ This is done for three income categories of households with two parents and two children (ages two and three). The first income category is a low-income household, with each spouse

\footnotetext{
16 The parent fee increases as family net income increases. See Annex II for more details.

${ }^{17}$ Low-income households have potential access to subsidized child care in more provinces, but these subsidized spaces are not guaranteed. Access depends not only on the family's financial situation, but also on the supply of these childcare spaces (see Macdonald and others 2016). In many provinces, about 90 percent of child care centers maintain waiting lists, with charges for families while they are waiting.

${ }^{18}$ See http://www.cra-arc.gc.ca/benefits-calculator/ and https://secure.ca.pwc.com/8525770E0077F8AB/ProdCalculators?Readform\&year=2016
} 
earning Can $\$ 19,000$ a year. If both spouses work, they earn Can $\$ 38,000$ annually, equivalent to half of Canadian median family income (Can\$78,870 in 2014). The second income category is a middle-income household, with each spouse earning Can $\$ 40,000$ annually (if two spouses work, their total income is about median family income). The third income category is a high-income household, with each spouse earning Can $\$ 97,000$ annually (top 10 percent in the distribution of household income). Data are for 2016.

\section{Results}

Figure 10 presents the estimates of marginal effective benefits in each province. A positive number indicates a net gain for the household (see Annex III for detailed calculations).

- For low-income families, Quebec's marginal effective benefit index is the highest, at 0.7. This implies that if a mother decides to work, total family gross income increases by $\$ 19,000$, and after paying income taxes and child care costs and receiving child care benefits, the family can still retain a net income increase of almost $\$ 14,000$. In contrast, in many other provinces, if a mother decides to work, her household's marginal benefit would be negative (except in Manitoba, and Prince Edward Island). For example, in Ontario, the marginal benefit index is -0.6 , indicating that the household's economy clearly worsens if the mother enters the labor market. Ontario has lower income taxes than other provinces, but this doesn't help much as its positive effect is more than offset by high child care fees. Indeed, the primary source of this difference arises from child care costs: in Quebec, due to generous public subsidies, the cost of child care is only about Can\$3,900 annually, but in Ontario, the cost is much higher at around Can $\$ 29,000$. 19

- For middle-income families, the marginal effective benefit index is positive for all provinces. However, in some provinces, it is around 0.3, implying that more than twothirds of the additional income earned by the secondary earner goes toward child care costs, income taxes, and reduced subsidies. For Ontario and British Columbia, the net gain is only marginally above zero. Quebec has the highest marginal benefit index, followed by Manitoba.

- For high-income families, the marginal effective benefit index is around 0.5. In the highincome case, the increase in income is more than sufficient to offset child care costs in all provinces.

\footnotetext{
${ }^{19} \mathrm{We}$ use 2016 childcare fees per province, calculated as population weighted averages of city data (data from Macdonald and others 2016). For the provinces where fees are related to income and where there are fee capsQuebec, Prince Edward Island, and Manitoba - fees for the different income groups have also been taken into account. As noted in footnote 16, there are also other specific childcare subsidies in provinces/territories for low income families, but there are no data available for different income groups. These specific subsidies are often related to family income, the number of children, family assets, and other factors such as children's special needs. The application process, done together with a social assistance worker, can be time consuming and accessibility is limited. Our calculations only include the conventional economic policy programs with publicly accessible childcare fee data.
} 
Figure 10. Marginal Effective Benefits, Today's Policy (Ratio)

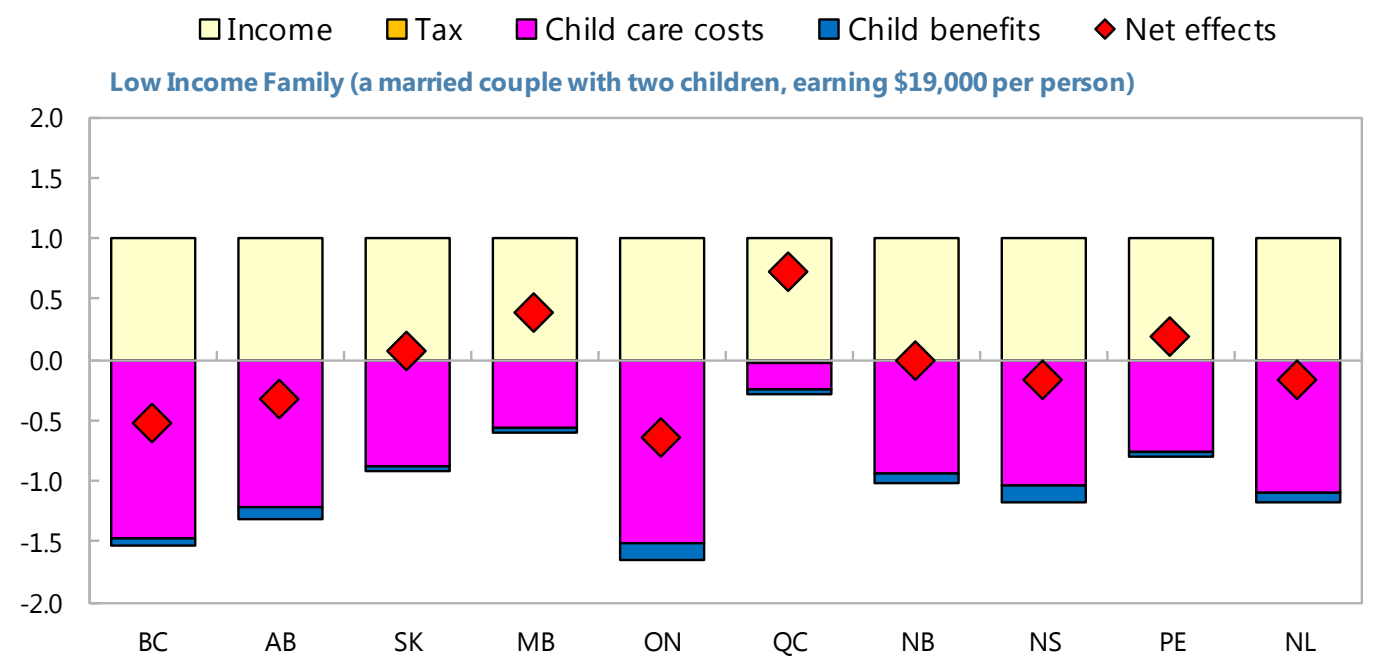

Middle Income Family (a married couple with two children earning $\$ 40,000$ per person)

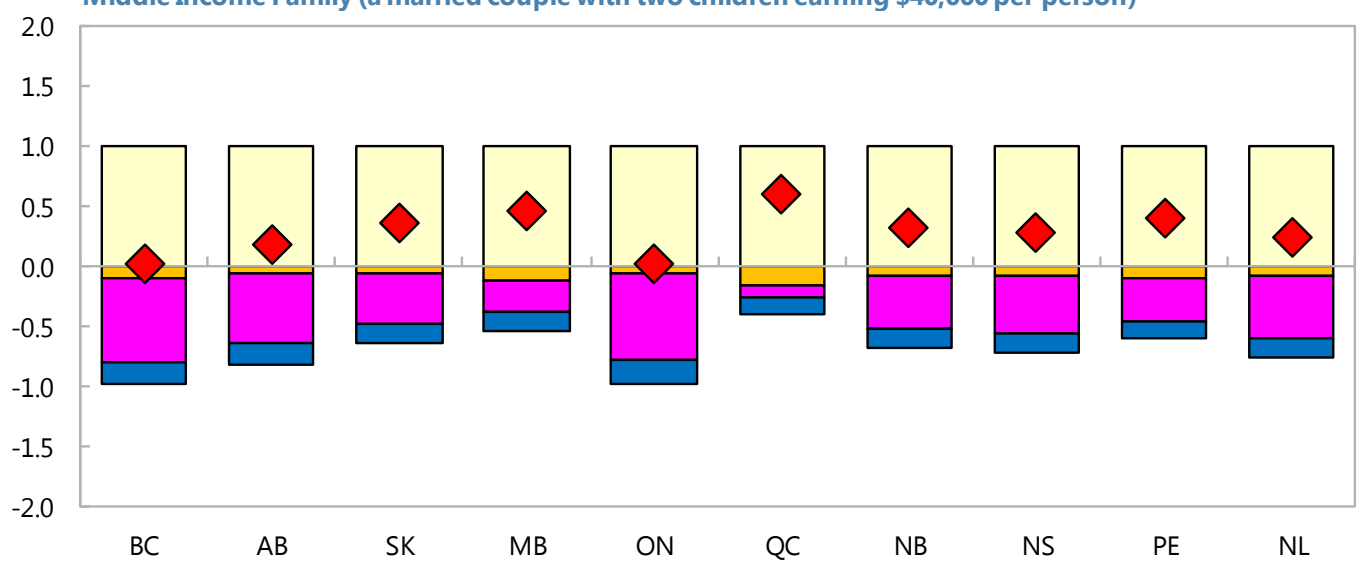

High Income Family (a married couple with two children earning $\$ 97,000$, per person)

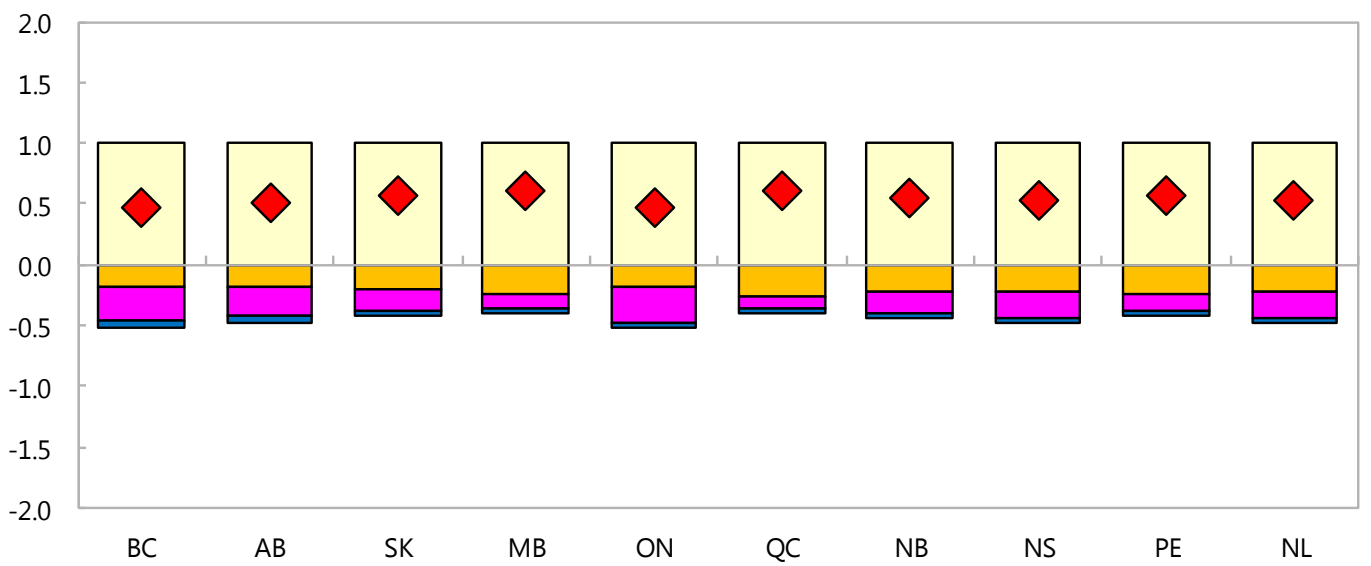

Sources: Canada Revenue Agency, Child and Family Benefits Calculator; and authors' calculations. 


\section{Discussion}

The universal Canada Child Benefit introduced in 2016 is generous and targeted to low- and middle-income families. However, it is universal in that it is not specifically targeted to employment, study, or the unemployed actively seeking employment. If one of the parents with children decides to stay at home to take care of their children, the couple is given more child benefits (because the family income is lowered), compared with a case when both parents work. In other words, the child benefit does not add an incentive to work or get job training.

If we assume that provision of child benefits is conditional on employment, study, or job training, and families with a "stay-at-home parent" are not entitled to receive the benefit, what would the marginal benefit index then look like? ${ }^{20}$ Figure 12 shows that for low-income households the total economic benefit of a spouse entering the labor market would be positive for all provinces, although only marginally so for British Columbia and Ontario. For Quebec, the total benefit would actually be higher than the increase in gross income. The marginal benefit would also improve for middle- and high- income families in all provinces.

These illustrative calculations show that Quebec offers greater economic incentives for women to work than do other provinces. Quebec's approach is unique in Canada in the sense that the provincial government focuses on a supply-side funding approach. Quebec authorities set the ceiling of the price of child care services to households and to compensate their operating costs, provide funding assistance to child care service providers. Several studies (e.g., OECD 2006 and UNICEF 2008) indicate that the supply-side funding

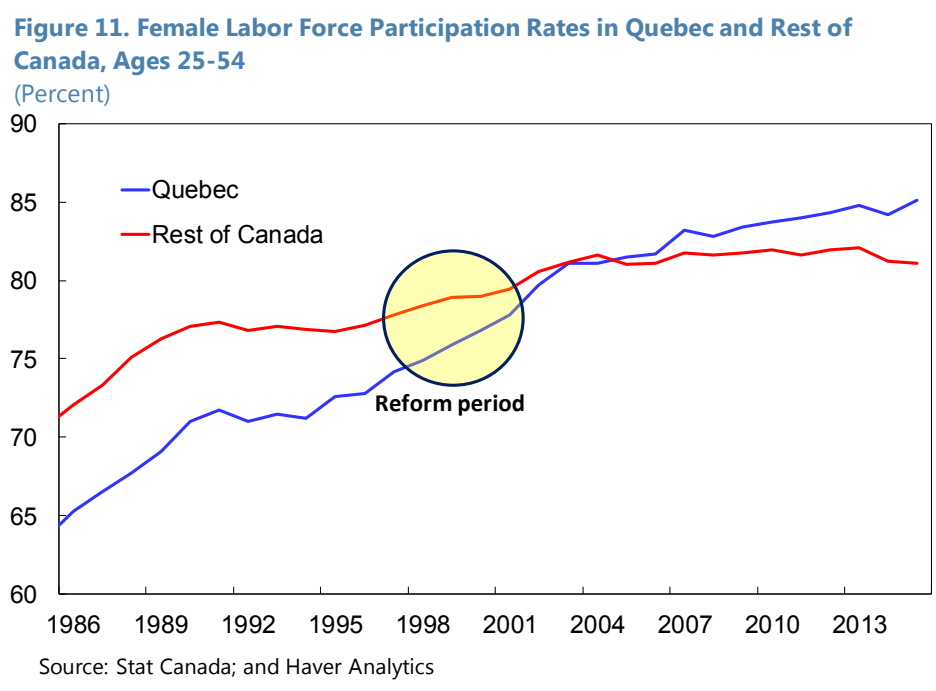
approach could result in more uniform quality and superior coverage of childhood populations than parent subsidy approaches. In fact, since the implementation of the major child care program reform in Quebec in 1997-2000, female labor force participation has increased faster than in the rest of Canada (Figure 11), a positive economic outcome highlighted in many studies (see Baker, Gruber and Milligan 2008; Lefebvre and Merrigan2008; and Fortin, Godbout, and St. Cerny 2012).

\footnotetext{
${ }^{20} \mathrm{We}$ are not questioning the benefit of income support for low-income families. Here, we are illustrating a scenario where child care benefits are more tied to employment.
} 
Figure 12. Marginal Effective Benefits, No Benefits for Families With a "Stay at home" Parent

\section{$\square$ Income $\quad \square$ Tax $\square$ Child care costs $\square$ Child benefits $\diamond$ Net effects}

Low Income Family (a married couple with two children, earning $\$ 19,000$ per person)

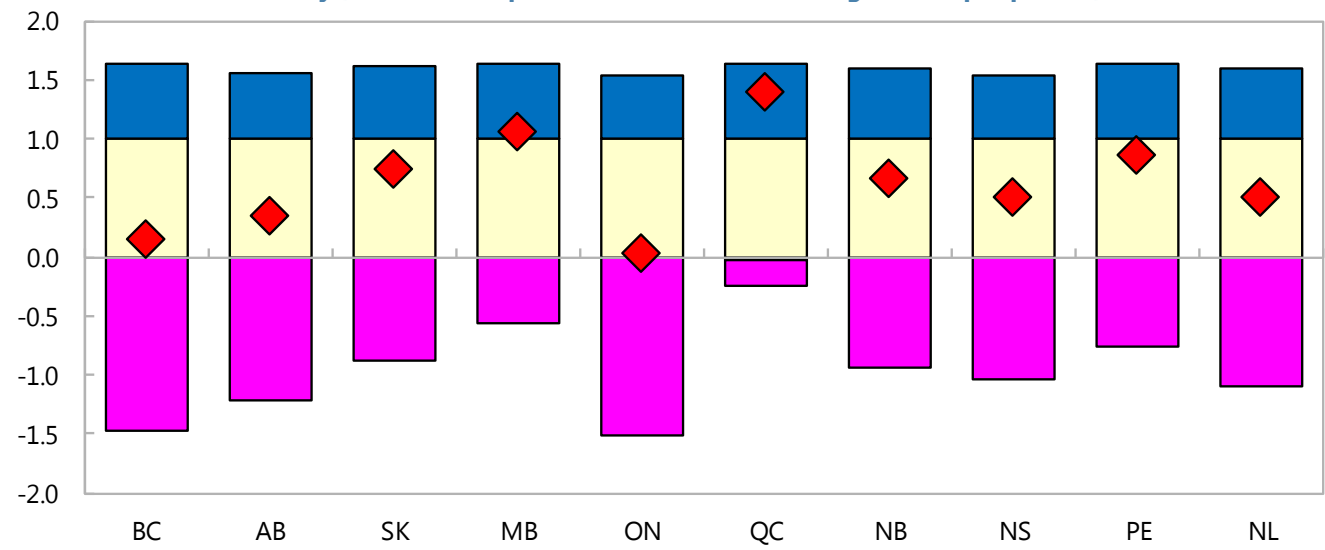

Middle Income Family (a married couple with two children earning \$40,000 per person)

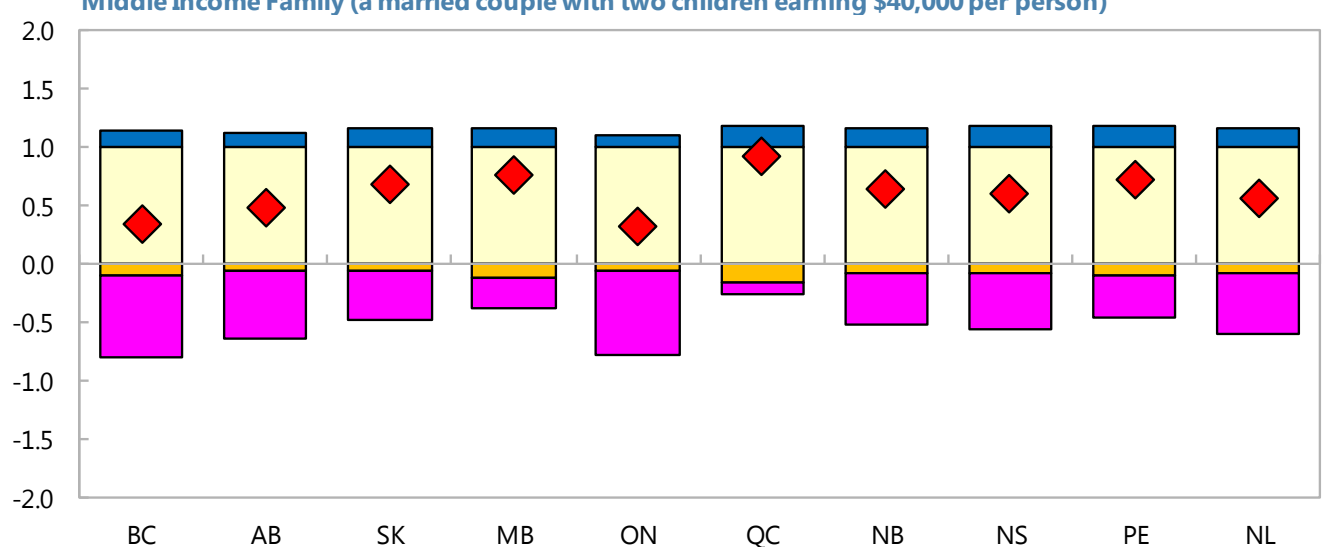

High Income Family (a married couple with two children earning $\$ 97,000$, per person)

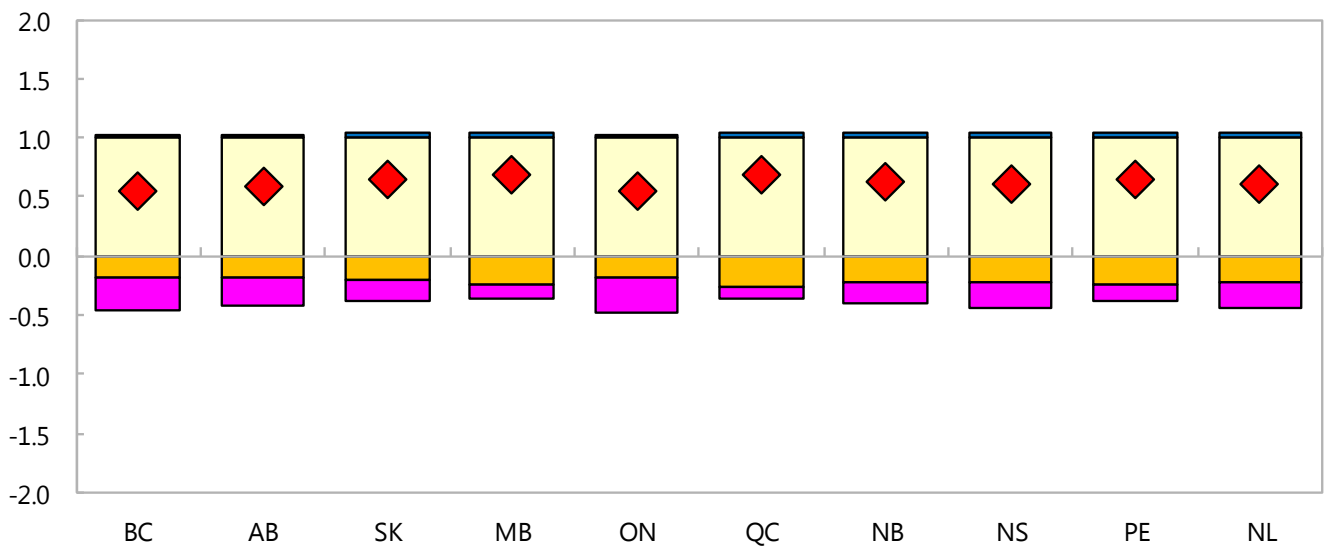

Sources: Canada Revenue Agency, Child and Family Benefits Calculator; and authors' calculations. 
As an illustration, we present another scenario: a new federal government funding program to help provinces fund for child care service providers. The national average child care fee is estimated at about Can $\$ 865$ per child a month. Suppose that to cut the fee by about 40 percent to Can $\$ 540$, the government pays providers the difference of Can $\$ 325$ (the total federal cost is estimated at Can $\$ 8$ billion, equivalent to 0.4 percent of GDP). We assume that this program would be tied to employment. ${ }^{21}$ Figure 13 suggests positive effects for all types of families, especially for low-income families.

This policy is fiscally affordable. Approximately 150,000 women are stay-at-home mothers with high educational attainment living with a spouse or a partner. If they all enter the labor market and start paying taxes, that would raise GDP by 2 percentage points, which would in turn raise federal income tax revenues by about Can $\$ 8$ billion, fully compensating the cost of the program. ${ }^{22}$ In other words, the program would be fully financed in a federal government perspective. ${ }^{23}$ Importantly, to achieve the policy goal of enhancing work incentive, access to subsidized child care fees should be conditional on employment. ${ }^{24}$

Figure 14 summarizes the marginal effective benefit under the three scenarios. Under the second scenario ("no benefits for families with a stay-at-home parent"), economic incentives for work would clearly improve, especially for low-income families and, to a lesser extent, middle-income families. This policy would also lead to fiscal savings but could be politically costly because "stay-at-home mother" families lose benefits. The third scenario ("subsidized child care fees") would give more uniform incentives across provinces, would be naturally targeted at working couples (ensuring only working couples have access to subsidized fees), and would be politically less sensitive, although the incentives are smaller than in the second scenario.

\footnotetext{
${ }^{21}$ Other assumptions are no change in the current Canada Child Benefit Program; and no change in the current provincial child care subsidy programs. Quebec and Manitoba are assumed to retain their own programs, which are more generous than this scenario.

${ }^{22}$ It is assumed that every 1 percent increase in GDP leads to an increase in federal tax revenues of about \$4 billion. See Table A1.9 in the 2017 federal budget.

${ }^{23}$ We have also calculated the marginal effective benefits and fiscal costs if the federal subsidy for child care providers would be increased from the $\$ 325$ to $\$ 665$ (which would help cap the child care fee for all households at Can\$200, closer to Can\$171 for Quebec). The results show a large improvement of marginal effective benefits to above 0.5 for low income families for all provinces. However, this is fiscally expensive, with total fiscal costs amounting to around $\$ 16$ billion (0.8 percent of GDP) per year.

${ }^{24}$ Various studies show that Quebec's child care program has paid for itself. Fortin and others (2012) estimated that the Quebec program induced nearly 70,000 more mothers to hold jobs than if no such program had existed-an increase of 3.8 percent in female employment-in 2008. They also estimated that Quebec's GDP was higher by about 1.7 percent, resulting in an increase in fiscal revenues, more than paying off the program cost. However, there are arguments against this view. Geloso and others (2017) argues that the employment effect is exaggerated in the Fortin and others study and that there was no positive net effect on public finances.
} 
Figure 13. Marginal Effective Benefits, Subsidized Child Care Fees

(Ratio)

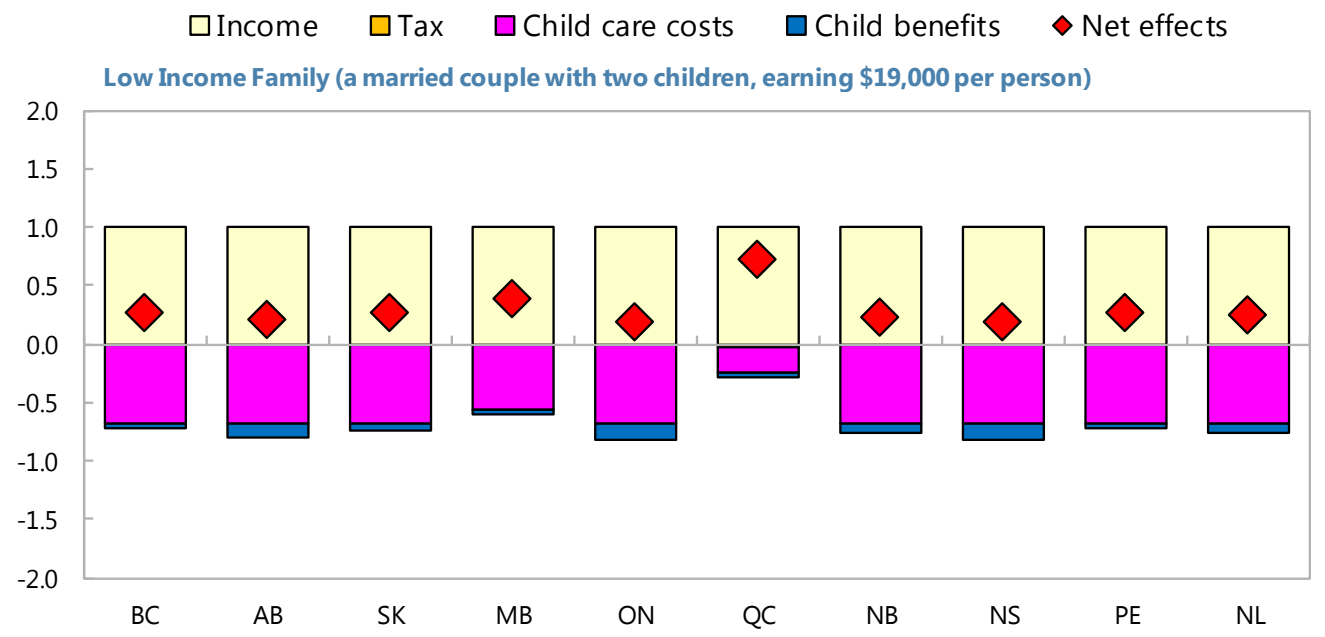

Middle Income Family (a married couple with two children earning $\$ 40,000$ per person)

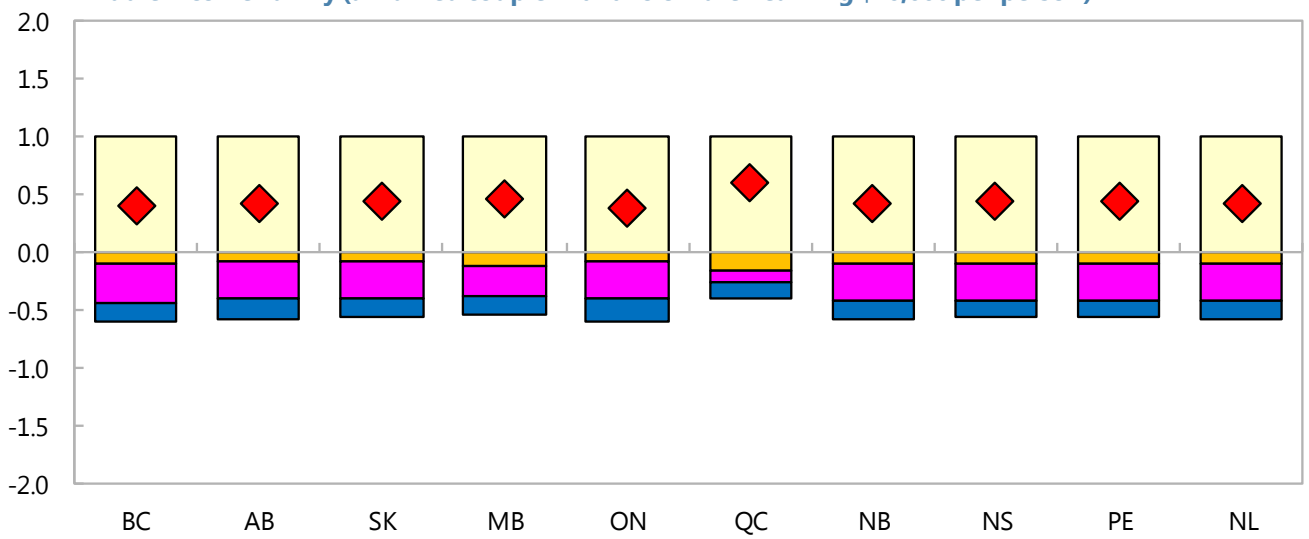

High Income Family (a married couple with two children earning $\$ 97,000$, per person)

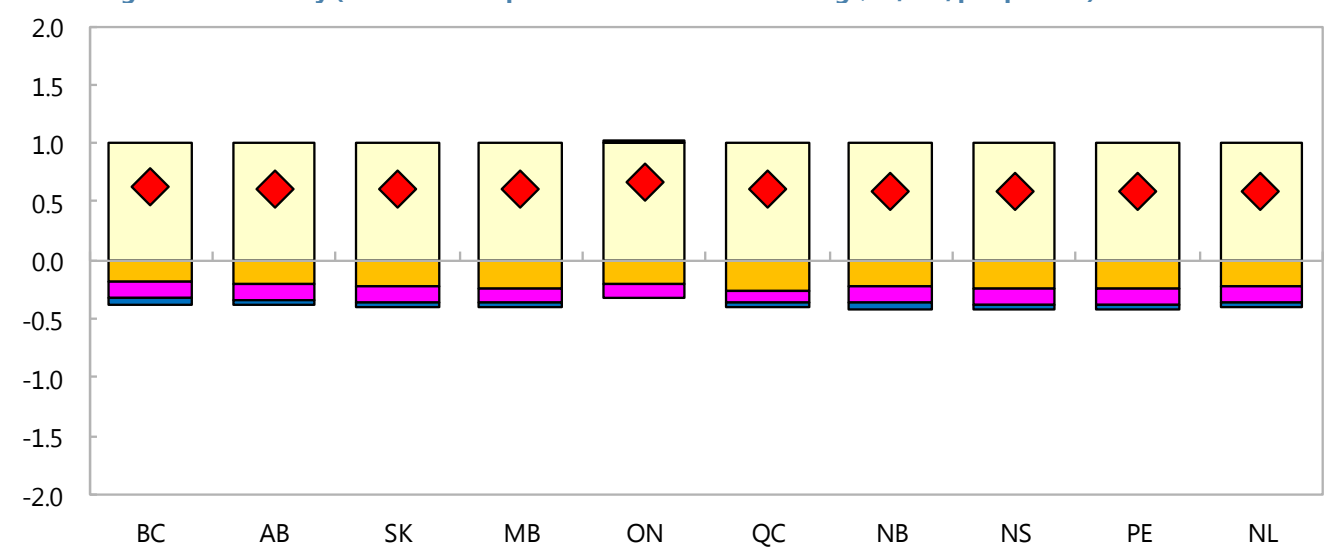

Sources: Canada Revenue Agency, Child and Family Benefits Calculator; and authors' calculations. 
Figure 14. Summary: Marginal Effective Benefits under Alternative Policies (Ratio)

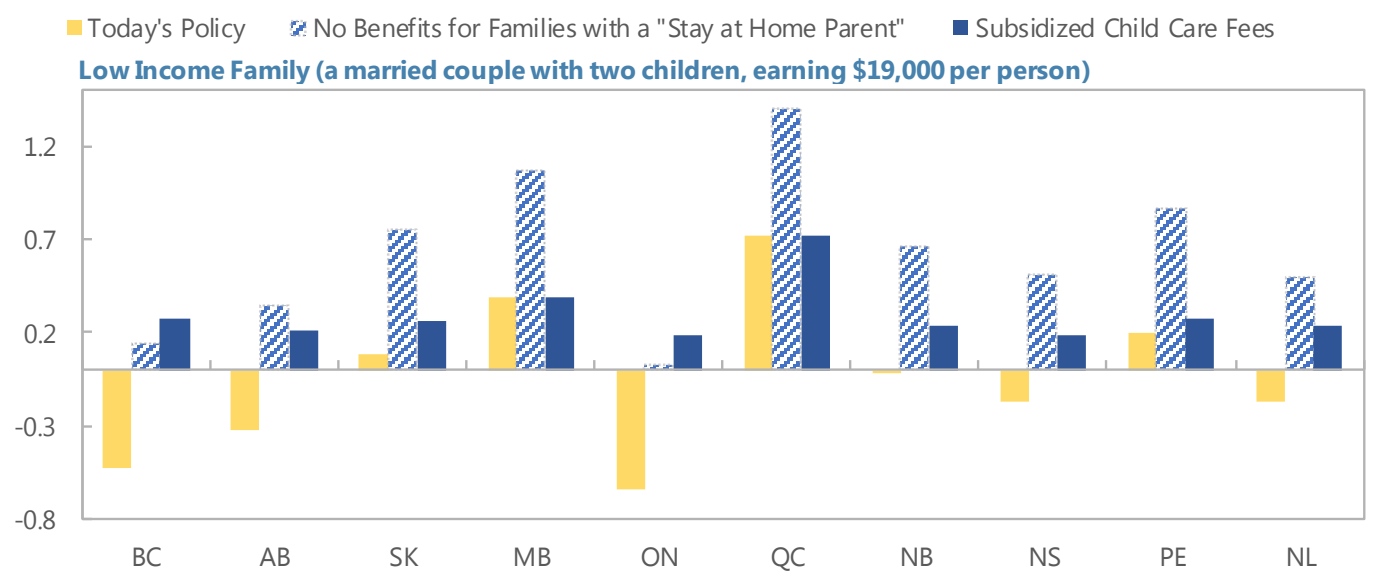

Middle Income Family (a married couple with two children, earning $\$ 40,000$ per person)

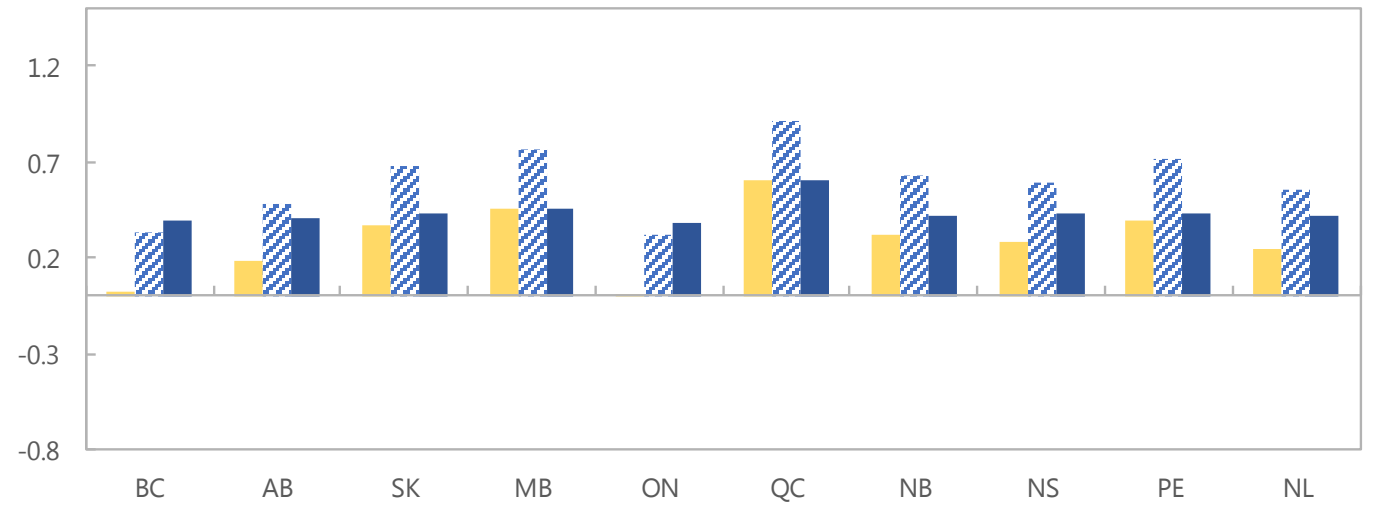

High Income Family (a married couple with two children, earning $\$ 97,000$ per person)

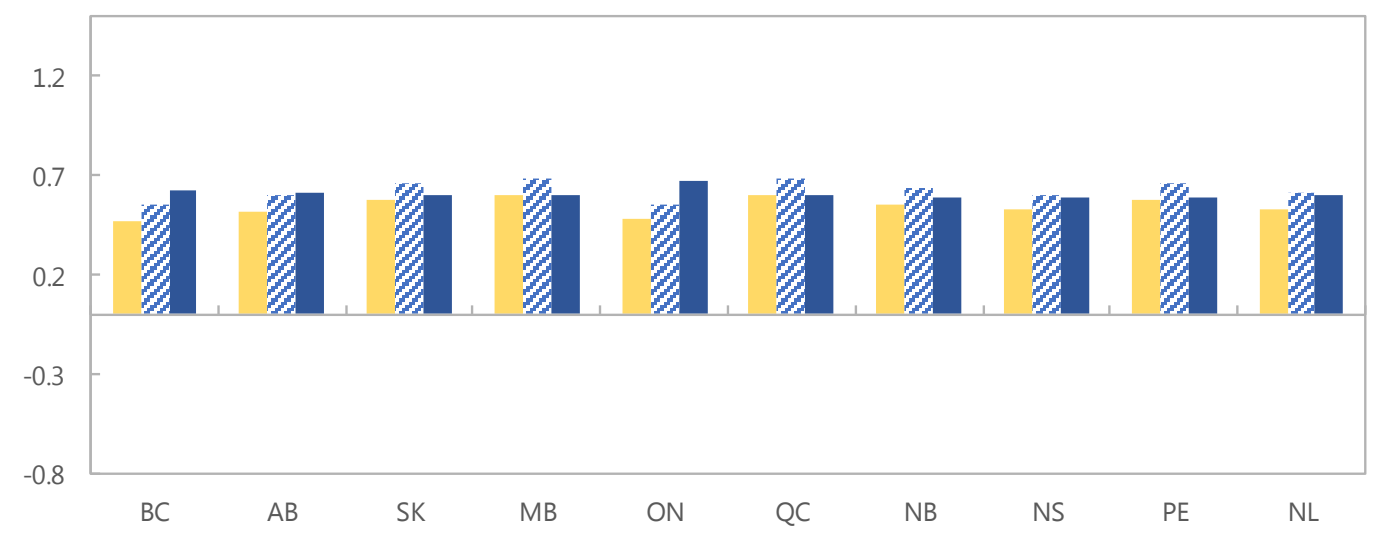

Sources: Canada Revenue Agency, Child and Family Benefits Calculator; and authors' calculations. 


\section{Tackling longstanding cultural norms to promote gender equality and increase economic growth}

Reform of child care assistance programs alone would not be sufficient to increase female labor force participation. The toughest question may be how to change social norms pertaining to the role of women. Longstanding cultural stigma often limits policy effectiveness. The low rate of fathers' usage of parental leave is a case in point.

While parental leave benefits can be shared between the parents, most fathers do not make much use of the benefit after the birth or adoption of children, except in Quebec (which has earmarked father-only leave in addition to parental leave). The available survey data on employment insurance suggest that in 2014, among all insured Canadian mothers, 89 percent received maternity or parental leave payments, whereas only 27 percent of fathers claimed parental leave benefits (Figure 15). In contrast,

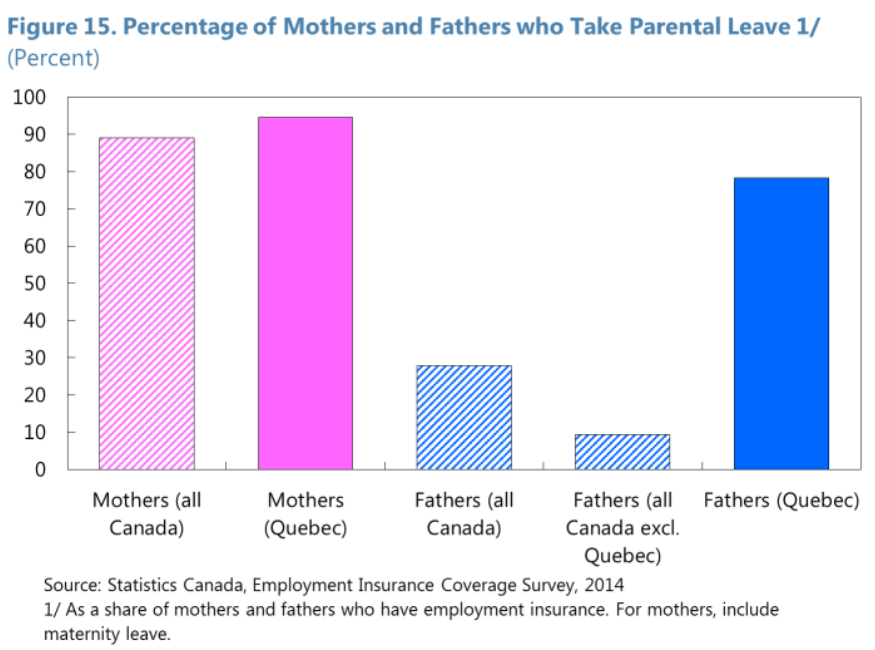
in Quebec, the share of fathers who took parental leave was 78.3 percent, nearly three times the national average (the share of mothers was also the highest, at 94.5 percent).

Several factors may explain why fathers are less likely to take leave outside of Quebec. Analyzing parental leave programs in European countries, Plantenga and Remery (2005) found five main determinants of take-up rates by fathers: payment level (financial impact); organizational and social culture (expected roles for men and women); program flexibility (when and how leave can be taken); work environment (employer attitude and perceived career advancement); and educational level of parents. Even in Canada, there is anecdotal evidence suggesting that stigma remains on fathers taking parental leave due to peer pressure and an unsupportive workplace (Paterson 2016). ${ }^{25}$

Thus, social factors are important. To achieve gender equality, for example in terms of wages that would further encourage women to enter the labor market, a more equal distribution of parental leave could be considered. One option is to introduce parental leave exclusively for fathers, a "daddy quota." Quebec and Nordic countries have implemented this policy, which seems effective in changing social norms toward a more gender-equal division of parenthood and work.

- Quebec has its own parental benefits program, called the Quebec Parental Insurance Plan, which the Quebec government introduced in January 2006, replacing a federal program

\footnotetext{
${ }^{25}$ Based on Employment Insurance Coverage Survey, Marshall (2008) discussed that the most common reason why fathers did not take paternity leave (40 percent of respondents) was "the preferred arrangement of the mother or the family." The second most common (20 percent) was "could not leave work". See also Bartel and others (2015) analyzing the case in the United States.
} 
(the Canada Employment Insurance Program). Quebec's program is more generous than the federal program, in terms of the eligibility criteria and the rate of income replacement. It also includes a five-week "daddy quota" of paternity leave. The introduction of the daddy quota has changed fathers' behavior quite significantly in Quebec: the incidence of fathers taking paternity leave rose from 32 percent in 2005 to 56 percent in 2006 (Marshall 2008).

- In Sweden, a "daddy quota" was first introduced in 1995 (Box 1). The Swedish Social Insurance Inspectorate (2012) found that the introduction of the measure had a significant impact on parents' leave patterns, with mothers' use of parental leave falling 26 days and fathers' use increasing by 10 days during the first two years of a child's life.

\section{Conclusions}

The main finding of this paper is that female labor force participation among well educated women has a positive effect on labor productivity. This finding is not a surprise. As well understood in the growth literature, an economy with many highly skilled workers is likely to be much more productive. Our analysis shows that if the current gap of 7 percentage points between male and female labor force participation with high educational attainment were eliminated, the level of real GDP could be about 4 percent higher today. This brings about 0.3 million women with high educational attainment in the labor market ${ }^{26}$. Today approximately 0.3 million highly educated "stay at home" mothers have at least one child under 5 years, of which nearly 0.2 million are living in a partner or spouse relationship. ${ }^{27}$. Thus a key element of labor market policies to encourage women to participate in the labor market should be to help improve the work-life environment for these women with young children.

Canada fares well in comparison with other OECD countries on most family policy indicators. Public spending on early education and care, however, is low. If high child care costs mean it is not economically worthwhile for women to work, it will be difficult to realize women's full potential in the work force. The latest policy initiatives to provide more affordable child care spaces are a positive step forward to encourage more women to participate in the labor market. However, we argue that to maximize the policy outcome given a budget constraint, provision of child care subsidies, including publicly funded child care spaces, should be better targeted to working parents, including those who study or take job training to improve their skills to obtain better jobs in the future.

\footnotetext{
${ }^{26}$ While our analysis has focused on highly educated women, increasing female labor force participation among less-educated women would also boost GDP as labor input increases.

${ }^{27}$ Calculated based on 2015 data in "Changing Profile of Stay at Home Parents," Statistics Canada, 2017, and 2014 data in "Lone-parent Families," Statistics Canada, 2015.
} 


\section{Box 1. The Swedish Parental Leave and Child Care System}

Sweden's female labor force participation rate and gender equality ranking —along with other Nordic countries - is among the highest in the world thanks to deliberate policy measures to improve gender equality.

Sweden has implemented two major policy measures to boost female labor force participation.

\section{Paternity leave}

Sweden implemented parental leave for fathers in 1974 and introduced one month of paternity leaveknown as "daddy month"- under "use it or lose it" conditions in 1995. The length of paternity leave has gradually increased and was extended to 3 months in January 2016.

Paternity leave has increased fathers' use of parental leave and stimulated more women to work, without decreasing male labor force participation. It has also dampened gender wage gaps (Johansson 2010).

\section{Affordable child care}

The supply of child care increased quickly in the 1970s and 1980s. This made it easier for mothers to work. In 2001-03 the federal government offered a large subsidy on child care costs to all municipalities in Sweden and set limits on maximum amounts for how much families would pay out of pocket for child care. No municipality rejected the offer.

The monthly limit is now Skr 1,362 28 (just over US\$150) a month for the first child; SKr 908 (about US $\$ 100$ ) for the second child; SKr 454 (about US\$50 for the third; and no cost for any additional children. This measure dramatically lowered household expenditures on child care. The main goal of the program is to encourage labor force participation. Eligibility for subsidized child care is linked to employment or studying, or if the child has special needs due to its family situation or physical, psychological, or other authorized reasons. Parents who are searching for and applying for jobs or on parental leave are given limited access to the program.

The program increased female labor participation, but only slightly because households' child care fees were already fairly low thanks to high subsidies compared with other developed economies (Lundin and others 2007) - it had, however, a stronger effect on the male labor supply. Studies from other countries with much lower subsidies to start with show much stronger labor supply effects. Another reason for the small effect on women's labor force participation might be that it was already high before the reform.

\footnotetext{
28 The limits were increased slightly in January 2017.
} 
Furthermore, bold decisions are needed to change corporate cultures and shift social norms. A glass ceiling apparently remains. For example, Canada's gender wage gap is well above the OECD average (the third highest among 20 advanced OECD economies), ${ }^{29}$ and progress in promoting women's representation in senior management has also been slow (the third lowest), with women making up only one in four senior managers. This glass ceiling could discourage younger generations of women to pursue professional careers. Addressing the problem would require concerted efforts from all stakeholders, including both the private and public sector. One option is to introduce parental leave for fathers, which seems to have been effective in Quebec and Nordic countries.

Since the global financial crisis, countries around the world have been trying to increase GDP growth. Canada is no exception. Low oil prices and weak growth in Canada's major trading partners have hampered its exports, and its aging population means the labor force is shrinking. Canada must speed up its labor productivity growth. Women are part of the solution: they can help offset the shrinking labor force, reverse the decline in labor productivity growth, boost medium-term growth potential, and raise the living standards of all Canadians.

\footnotetext{
${ }^{29}$ In recent decades, the gender wage gap (taking into account age, education, marital status, union status, tenure, industry, and occupation) decreased in almost all provinces, but a fairly large gender wage gap remains. Governments at both the federal and the provincial level have introduced pay equity legislation for public sector employees (and in some cases also for the private sector employees). To some extent, this has proved effective: in those provinces that adopted the legislation early, such as New Brunswick, Nova Scotia, and Prince Edward Island, the gender wage gap has shrunk faster than in the others (for decreasing gender wage gaps, see Schirle 2015). The 2016 and 2017 federal government budgets also included measures aimed at reducing the gender wage gap, but an unexplainable wage gap remains.
} 


\section{REFERENCES}

Arellano, M., and S. Bond, 1991, "Some Test of Specification for Panel Data: Monte Carlo Evidence and an Application to Employment Equations," Review of Economic Studies, Vol. 58, pp. 277-297.

Arellano, M., and O. Bover. 1995, "Another Look at the Instrumental Variable Estimation of Error-components Models.” Journal of Econometrics, Vol. 68, pp. 29-51.

Baker, M., J. Gruber and K. Milligan, 2005, "Universal Child Care, Maternal Labor Supply and Family Well-Being,," NBER Working Paper Series, Working Paper 11832, National Bureau of Economic Research.

Bank of Canada, 2016, Monetary Policy Report (April 2016).

Barrow, R.J., and J.W. Lee, 1993, "International Comparisons of Educational Attainment," Journal of Monetary Economics, 32, 363-94. and Implications,” Oxford Economic Papers 53(3).

Bartel, A., M. Rossin-Slater, C. Ruhm, J. Stearns, and J. Waldfogel, 2015, "Paid Family Leave, Fathers' Leave Taking, And Leave Sharing in Dual Earner Households," NBER Working Paper Series, Working Paper 21747, National Bureau of Economic Research.

Bibbee, A., 2008, “Tax Reform for Efficiency and Fairness in Canada," OECD Economics Department Working Paper, No. 631, ECO/WKP(2008)39.

Blundell, R., and S. Bond, 1998, "Initial Conditions and Moment Restrictions in Dynamic Panel Data Models." Journal of Econometrics, Vol. 87, pp. 115-143.

Chaykowski, R.P., and L.M. Powell, 1999, "Women and the Labor Market: Recent Trends and Policy Issues," Canadian Public Policy, Vol. XXV Supplement 1, S1-S25.

Coulombe, S., and F. Lee, 1995, "Convergence Across Canadian Provinces, 1961 to 1991," Canadian Journal of Economics, 24, pp. 886-98.

Crossley, T.F., and S.H., Jeon, 2006, “Joint Taxation and the Labor Supply of Married Women: Evidence from the Canadian Tax Reform of 1988," Social and Economic Dimensions of an Aging Population Research Papers, 149, McMaster University.

Feyrer, J., 2007, "Demographics and Productivity," The Review of Economics and Statistics, 89(1):100-109.

Fortin, Pierre, L. Godbaut, S. St-Cerny, 2012, “Impact of Quebec's Universal Low-Fee Childcare Program on Female Labour Force Participation, Domestic Income, and Government Budgets". 
Geloso, V. and B. Eisen, 2017, “Quebec's Daycare Program A Flawed Policy Model,” Fraser Research Bulletin.

Goldin, C., 2006, "The Quiet Revolution That Transformed Women's Employment, Education, and Family," American Economic Review, Vol. 96, pp. 1-21.

Guellec, D. and B. Van Pottelsberghe de la Potterie. 2004. "From R\&D to Productivity Growth: Do the Institutional Settings and the Source of Funds of R\&D Matter?" Oxford Bulletin of Economics and Statistics, Vol 66, pp. 353-378.

Hayakawa, K., 2009, "On the Effect of MeanNonstationarity in Dynamic Panel Data Models," Journal of Econometrics, Vol. 153, pp. 133-135

International Monetary Fund, 2013, "Women, Work, and the Economy: Macroeconomic gains from Gender Equality," Staff Discussion Notes, No. 13/10, International Monetary Fund, Washington D.C.

International Monetary Fund, 2016, "Canada 2016 Article IV Consultation-Press Release; and Staff Report, June 2016, International Monetary Fund, Washington D.C.

International Monetary Fund, 2017, "Women, Work and Economic Growth, Leveling the Playing Field," International Monetary Fund, Washington D.C.

Jaumotte, F., 2003, "Female Labor Force Participation: Past Trends and Main Determinants in OECD Countries," Economics Department Working Paper No. 376, OECD, Paris.

Johansson, Elly-Ann, 2010, "The Effect of Own and Spousal Parental Leave on Earnings" (2010), Institute of Evaluation of Labour Market and Education Policy, Working Paper 2010:4.

Lee, F., and S. Coulombe. 1995, "Regional Productivity Convergence in Canada." Canadian Journal of Regional Science, Vol. 18, pp. 39-56.

Lefebvre, P. and P. Merrigan, 2008, "Child-Care Policy and the Labor Supply of Mothers With Young Children: A Natural Experiment From Canada,” Université du Québec à Montréal.

Lundin, D., E. Mörk and B. Öckert, "Do reduced child care prices make parents work more?" IFAU - Institute for Labour Market Policy Evaluation, Working paper 2007:2.

Macdonald, David and M. Friendly. 2016, "A Growing Concern, 2016 Child Care Fees in Canada’s Big Cities,” Canadian Center for Policy Alternatives, December 2016.

Mankiw, N.G., D, Romer, and D.N. Weil, 1992, "A Contribution to the Empirics of Economic Growth," The Quarterly Journal of Economics, 107(2): 407-437

Marshall, Katherine, 2008, “Fathers' use of paid parental leave”, (2008), Statistics Canada, June 2008 Perspectives - Catalogue no. 75-001-X. 
OECD, ILO, IMF, and World Bank, 2014, "Achieving Stronger Growth by Promoting a More Gender Balanced Economy," Report prepared for the G20 Labor and Employment Ministerial Meeting Melbourne, Australia, 10-11 September 2014.

OECD, 2016, "Starting Strong II, Early Childhood Education and Care,” 2006.

OECD, 2017, “Gender Wage Gap Indicator,” https://data.oecd.org/earnwage/gender-wagegap.htm

Pesaran, M.H. and R.P. Smith. 1995. "Estimating Long-run Relationships from Dynamic Heterogeneous Panels." Journal of Econometrics, Vol. 68, pp. 79-113.

Paterson, J., 2016, "How to Bridge the Parental Leave Divide," Benefits Canada

Phillips, P.C.B., and D. Sul, 2007, "Bias in Dynamic Panel Estimation with Fixed Effects, Incidental Trends and Cross Section Dependence.” Journal of Econometrics, Vol. 137, pp. $162-188$.

Plantenga, J., and C. Remery, 2005, "Reconciliation of work and private life. A comparative review of thirty European countries," Office for Official Publications of the European Communities, Luxemburg.

Rodrik, D., 2013, "Unconditional Convergence in Manufacturing." Quarterly Journal of Economics, Vol. 128, pp. 165-204.

- ——— 2009a, "How to Do xtabond2: An Introduction to Difference and System GMM in Stata." The Stata Journal, Vol. 9, pp. 86-136.

____ - 2009b, "A Note on the Theme of Too Many Instruments." Oxford Bulletin of Economics and Statistics, Vol 71, pp. 135-158.

Sarlo, C., 2016, "Child Care in Canada: Examining the Status Quo in 2015," Fraser Institute.

Schirle, T. "The Gender Wage Gap in the Canadian Provinces, 1997-2014," Department of Economics, Wilfrid Laurier University, Waterloo, Ontario, 2015.

Skirbekk, V., 2003, “Age and Individual Productivity: A Literature Survey,” MPIDR Working Paper WP 2003-028, August 2003.

Statistics Canada, "Changing profile of stay-at-home parents," 2017.

Statistics Canada, "Lone-parent families," 2015.

Statistics Canada, 107, "Women in Canada: A Gender-based Statistical Report, Women and Paid Work."

Swedish Social Insurance Inspectorate, 2012, "Genderequal Sharing? Reforms within parental Leave Insurance,” ISF Report 2012:3. 
Thévenon O, and A. Solaz (2013), "Labour Market Effects of Parental Leave Policies in OECD Countries," OECD Social, Employment and Migration Working Papers, No.141, OECD, Paris.

Tsounta, E., 2006, "Why Are Women Working So Much More in Canada? An International Perspective," IMF Working Paper WP/06/92.

UNICEF, "Early Childhood Services in the OECD Countries: Review of the Literature and Current Policy in the Early Childhood Field," 2008.

United States Department of Labor, 2015, "Paternity Leave, Why Parental Leave for Fathers Is So Important for Working Families," Dol Policy Brief.

Uppal, S., 2015, “Employment Patterns of Families with Children," Insights on Canadian Society, Statistics Canada Catalogue no. 75-006-X, June. 


\section{Annex I. Data Description}

\section{Data used for regressions in Section II. C.}

- Labor productivity growth. In percent. The first difference of the logarithm of real GDP per hour worked (total hours worked, for all jobs, both sexes, from 15 years old and over).

- Level of labor productivity (t-1). In logarithm. Calculation is such that for 1990-94 the variable takes the value as of 1989, for 1995-99 takes the value as of 1994, and so on up to 2015 .

- $\quad$ R\&D stock per hour worked ( $t-1)$ : In logarithm. Calculated such that for 1990-94 takes the value as of 1989, for 1995-99 takes the value as of 1994, and so on up to 2015.

- Growth of external exports. In percent. The growth rate of exports of goods and services in Canadian dollars to other nations.

- Growth of intra-provincial trade. In percent. The growth rate of exports of goods and services in Canadian dollars to other provinces.

- Growth of capital stock per hour worked. In percent. The first difference of the logarithm of real capital stock (nonresidential) per hour worked.

- Change in net migration in provinces to population. In percentage points. The change in the ratio of net interprovincial migration to population (inflows minus outflows).

- Index of rule of law. Calculated by the Worldwide Governance Indicators for Canada as a whole. This variable is a proxy for the quality of institutions.

- $\quad$ Fertility rates. In logarithm. The number of births to the female population. This variable is used as an instrument for female labor participation variables. This captures the long-term decisions of women's career.

- Index of voice and accountability. Calculated by the Worldwide Governance Indicators for all Canada. This reflects perceptions of the extent to which a country's citizens can participate in selecting their government, as well as freedom of expression, freedom of association, and a free media. This is used as a proxy for a female-friendly environment and an instrument for female labor participation variables.

- Female legislators, senior officials and managers. In percent. The share of legislators, executives, and managers who are women, and for Canada as a whole. This serves as a proxy for the role model effect, expected career improvement, and a measure of female 
access to nontraditional jobs, and is used as an instrument for female labor participation variables.

- Female labor force participation variables: all variables are measured in percent of total female population in the same age cohort. The denominator is the total female population in the age and group category while the numerator is the labor force in the same age and group. The groups are the following:

- High degree: postsecondary certificate, diploma, bachelor's degree, or university degree.

- Low degree: 0 to 8 years of school, some high school, high school graduate, or some postsecondary.

- Fully employed: a woman who usually work 30 hours or more per week at her main or only job.

\section{Other data}

- Tax wedge on secondary earners. Following Jaumotte (2003), defined as the tax wedge between second earner and single individual at 67 percent and 100 percent of average production worker earnings (APW).

It is calculated as the share of her earnings that goes into paying additional household taxes as follows:

Tax secondary earner $=1-\frac{(\text { Houshold Net Income })_{D}-(\text { Household Net Income })_{S}}{(\text { Houshold Gross Income })_{D}-(\text { Household Gross Income })_{S}}$ where $s$ denotes the situation in which the wife does not earn any income and D denotes the situation in which the wife's gross earnings are 67 percent (100 percent respectively) of APW. It is assumed that the secondary earner's husband earns 100 percent of APW and that the couple has two children. The difference between gross and net income includes income taxes, employee's social security contribution, and universal cash benefits. 
Annex 1. Table 1. Descriptive Statistics

(Calculations by province from 1980-2015, 5-year averages)

\begin{tabular}{|c|c|c|c|c|c|}
\hline & Count & Mean & Std.Dev. & Min & Max \\
\hline Labor productivity growth & 70 & 1.2 & 1.1 & -1.0 & 5.4 \\
\hline Level of labor productivity & 70 & 7.7 & 0.2 & 7.2 & 8.2 \\
\hline$R \& D$ stock per hour worked & 70 & 4.8 & 0.4 & 4.2 & 5.7 \\
\hline Growth of external exports & 70 & 6.5 & 4.8 & -4.7 & 17.1 \\
\hline Growth of intra-provincial trade & 70 & 4.9 & 3.9 & -3.1 & 28.1 \\
\hline Growth of capital stock per hour worked & 70 & 1.3 & 1.6 & -2.8 & 6.7 \\
\hline Change in net-migration in provinces to population & 70 & 0.0 & 0.2 & -0.8 & 0.3 \\
\hline Index of rule of law & 70 & 1.5 & 0.3 & 1.0 & 1.8 \\
\hline Fertility rate (births per woman) & 70 & 0.2 & 0.3 & -0.3 & 0.7 \\
\hline Index of voice and accountability & 70 & 1.6 & 0.1 & 1.4 & 1.6 \\
\hline Female legislators, senior officials and managers (\% of total) & 60 & 34.8 & 2.2 & 30.4 & 36.4 \\
\hline Females labor force participation rate & 70 & 75.3 & 8.4 & 49.0 & 87.0 \\
\hline Female labor force participation rate with high education attainment & 50 & 86.4 & 2.3 & 81.9 & 91.3 \\
\hline Female full-time employed participation rate with high education attainn & 50 & 65.6 & 4.4 & 58.6 & 73.7 \\
\hline Female part-time employed participation rate with high education attain & 50 & 16.1 & 3.2 & 10.1 & 22.9 \\
\hline Female labor force participation rate with low education attainment & 50 & 70.6 & 6.6 & 49.9 & 80.2 \\
\hline Male labor force participation rate with high education attainment & 50 & 94.0 & 1.6 & 88.9 & 96.2 \\
\hline
\end{tabular}

Source: Authors' calculations. 


\section{Annex I Figure 1. Female Labor Participation Rates and Labor Productivity Growth} by Province

Females Labor Force Participation, 25 to 54 Years (percent) and Labor Productivity Growth In percent over 5 -year averages

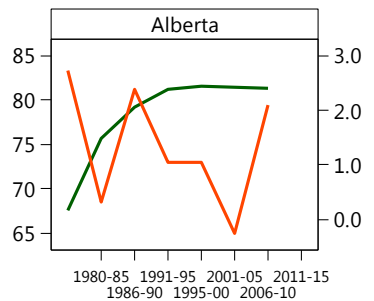

$\begin{array}{llll}980-85 & 1991-95 & 2001-05 & 2011-15 \\ 1986-90 & 1995-00 & 2006-10\end{array}$
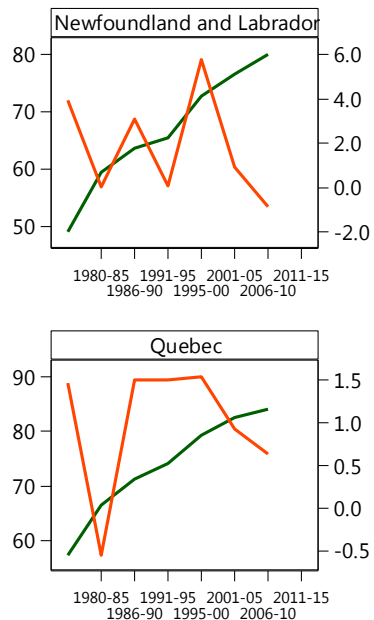
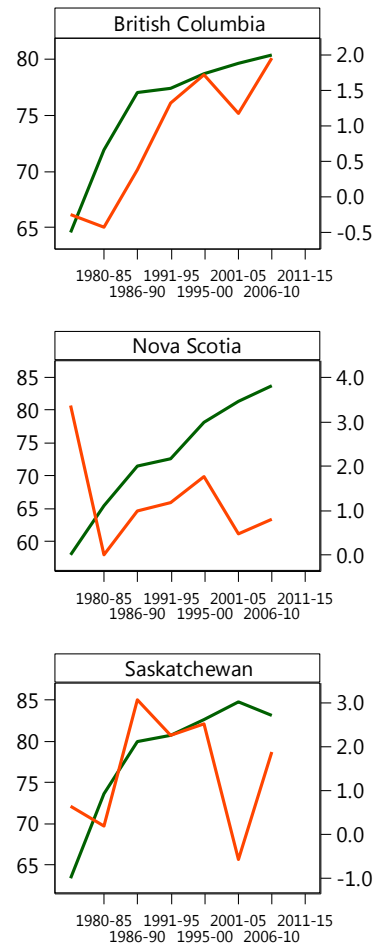
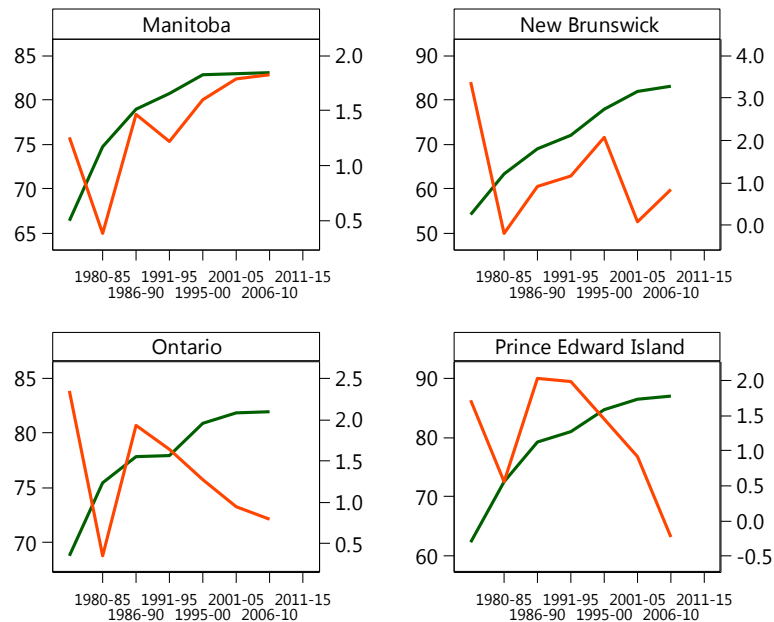
Annex II. Child Benefit and Day Care Subsidy Programs by Province

(As of October 2016, in Canadian dollars)

\begin{tabular}{|c|c|c|c|c|}
\hline \multirow{2}{*}{ Province } & \multicolumn{2}{|c|}{ Child Benefit } & \multicolumn{2}{|c|}{ Child Day Care } \\
\hline & Maximum Benefit (annual) & Income thresholds & Major subsidy program & Parent fees \\
\hline \multirow{5}{*}{$\begin{array}{l}\text { Newfoundland and } \\
\text { Labrador } \\
\text { (The Newfound land and } \\
\text { Labrador Child Benefit) }\end{array}$} & Under age 18 & Income tested & Set up and equipment grants & \multirow{5}{*}{$\begin{array}{l}\text { No administratively set fee except } \\
\text { for child care centers participating } \\
\text { in the Operating Grant Program. }\end{array}$} \\
\hline & \multirow{4}{*}{$\begin{array}{l}1 \text { child: } \$ 379 \\
2 \text { children: } \$ 781 \\
3 \text { children: } \$ 1,213 \\
4 \text { children: } \$ 1,676\end{array}$} & \multirow{4}{*}{$\begin{array}{l}\text { Below } \$ 17,397 \text { : full benefit } \\
\text { Between } \$ 17,397 \text { and } \$ 24,877 \text {, } \\
\text { reduced amount }\end{array}$} & $\begin{array}{l}\text { Early Leading and Child Care } \\
\text { Supplement. wage subsidies }\end{array}$ & \\
\hline & & & & \\
\hline & & & $\begin{array}{l}\text { Capacity Initiative: funding child care } \\
\text { in rural and underserves communities }\end{array}$ & \\
\hline & & & $\begin{array}{l}\text { Operating Grant Program: more } \\
\text { affordable child care }\end{array}$ & \\
\hline \multirow{4}{*}{$\begin{array}{l}\text { Prince Edward Island } \\
\text { (Child Care Subsidy } \\
\text { Program) }\end{array}$} & \multirow[t]{4}{*}{ Not available } & \multirow{4}{*}{$\begin{array}{l}\text { Income tested } \\
\text { The subsidy rate varies, depending } \\
\text { on the size of the family, age of } \\
\text { children, and the household's } \\
\text { income }\end{array}$} & \multirow{4}{*}{$\begin{array}{l}\text { Early Years Center Funding: fee } \\
\text { subsidies }\end{array}$} & \multirow{4}{*}{$\begin{array}{l}\text { Early Years Centers are subject to } \\
\text { administratively set daily fees } \\
\text { (per day) } \\
\text { Age 0-2: } \$ 34 \\
\text { Age 2-3: } \$ 28 \\
\text { Age 3-school entry: } \$ 27\end{array}$} \\
\hline & & & & \\
\hline & & & & \\
\hline & & & & \\
\hline \multirow[b]{2}{*}{$\begin{array}{l}\text { Nova Scotia } \\
\text { (Nova Scotia Child Benefit) }\end{array}$} & Under age 18 & Income tested & \multirow{2}{*}{$\begin{array}{l}\text { Early Childhood Enhancement Grants: } \\
\text { wage and operating costs subsidies }\end{array}$} & \multirow[t]{2}{*}{ No administratively set fee } \\
\hline & $\begin{array}{l}1^{\text {st }} \text { child: } \$ 625 \\
2^{\text {nd }} \text { child: } \$ 825 \\
3^{\text {rd }} \text { and each additional child: } \\
\$ 900\end{array}$ & $\begin{array}{l}\text { Below } \$ 18,000 \text { : full benefit } \\
\text { Between } \$ 18,000 \text { and } \$ 26,000 \text {, } \\
\text { reduced amount }\end{array}$ & & \\
\hline \multirow[b]{2}{*}{$\begin{array}{l}\text { New Brunswick } \\
\text { (New Brunswick Child Tax } \\
\text { Benefit and New } \\
\text { Brunswick Working } \\
\text { Income Supplement) }\end{array}$} & Under age 18 & Income tested & Capita funding and start-up funding & \multirow[t]{2}{*}{ No administratively set fee } \\
\hline & $\begin{array}{l}\text { New Brunswick Child Tax } \\
\text { Benefit: } \$ 250 \text { for each } \\
\text { dependent child } \\
\text { New Brunswick Working } \\
\text { Income Supplement: } \$ 250 \\
\text { for each dependent child }\end{array}$ & $\begin{array}{l}\text { New Brunswick Child Tax Benefit: } \\
\text { Below } \$ 20,000 \text { : full benefit } \\
\text { Above } \$ 20,000 \text {, less } 2.5 \text { percent of } \\
\text { family net income over } \$ 20,000 \text { for } \\
\text { one child families; or } 5 \text { percent of }\end{array}$ & $\begin{array}{l}\text { Training assistance } \\
\text { Quarterly improvement funding: wage } \\
\text { subsidies }\end{array}$ & \\
\hline
\end{tabular}




\begin{tabular}{|c|c|c|c|c|c|c|}
\hline \multirow{2}{*}{ Province } & \multicolumn{4}{|c|}{ Child Benefit } & \multicolumn{2}{|c|}{ Child Day Care } \\
\hline & Maximum Benefit (annual) & & \multicolumn{2}{|c|}{ Income thresholds } & Major subsidy program & Parent fees \\
\hline & \multicolumn{4}{|c|}{$\begin{array}{l}\text { New Brunswick Working Income } \\
\text { Supplement: the lesser of, } \$ 250 \\
\text { annually per family, or } 4 \% \text { of family } \\
\text { earned income over } \$ 3,750 \text { minus } \\
5 \% \text { of family net income over } \\
\$ 20,921 \text {. }\end{array}$} & 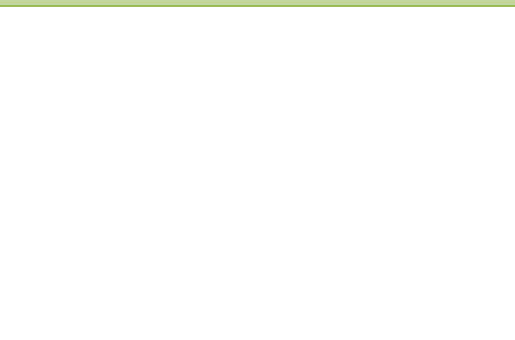 & \\
\hline $\begin{array}{l}\text { Quebec } \\
\text { (Child Assistance } \\
\text { Payment) }\end{array}$ & $\begin{array}{l}\text { Under age } 18 \\
1^{\text {st }} \text { child: } \$ 2,392 \\
2^{\text {nd }} \text { child: } \$ 1,195 \\
3^{\text {rd }} \text { child: } \$ 1,195 \\
4^{\text {th }} \text { and each additional child: } \\
\$ 1,793\end{array}$ & \multicolumn{3}{|c|}{$\begin{array}{l}\text { Income tested } \\
\text { For the case of one child, below } \\
\$ 41,917 \text { : full benefit } \\
\text { Regardless the level of income, } \\
\text { minimum benefit is set as following. } \\
1^{\text {st }} \text { child: } \$ 671 \\
2^{\text {nd }} \text { child: } \$ 620\end{array}$} & $\begin{array}{l}\text { All regulated child care centers (Center } \\
\text { de la Petite Enfance) and day care } \\
\text { centers (Garderies) are publicly } \\
\text { funded. }\end{array}$ & $\begin{array}{l}\text { Basic contribution: } \$ 7.55 \text { per day, } \\
\text { per child, if net family income } \leq \\
\$ 50,545 \text {. At an income of } \\
\$ 75,820 \text {, the daily rate starts } \\
\text { rising gradually, reaching } \$ 20.70 \\
\text { per day at an income of } \\
\text { approximately } \$ 158820 \text {. } \\
\text { Additional contributions: as of an } \\
\text { income of } \$ 50545 \text {, the additional } \\
\text { contribution is } \$ 0.70 \text { per day, for } \\
\text { a daily rate of } \$ 8.25 \text {. As of an } \\
\text { income of } \$ 75820 \text {, the additional } \\
\text { contribution increases gradually } \\
\text { until it reaches } \$ 13.15 \text { per day, } \\
\text { which corresponds to an income } \\
\text { of } \$ 158820 \text {, for a maximum daily } \\
\text { rate of } \$ 20.70 \text {. }\end{array}$ \\
\hline \multirow[b]{3}{*}{$\begin{array}{l}\text { Ontario } \\
\text { (Ontario Child Benefit) }\end{array}$} & \multicolumn{4}{|c|}{ Under age 18 , and income tested } & \multirow{3}{*}{$\begin{array}{l}\text { Capital Funding for New Construction } \\
\text { of Child Care } \\
\text { Operating funding }\end{array}$} & \multirow[t]{3}{*}{ No administratively set fee } \\
\hline & & $\$ 20,706$ & $\frac{\text { Net incom }}{\$ 25,000}$ & $\overline{\$ \$ 30,000}$ & & \\
\hline & $\begin{array}{l}\text { Number of } \\
\text { children } \\
1 \\
2 \\
3 \\
4\end{array}$ & $\begin{array}{l}\$ 113.00 \\
\$ 226.00 \\
\$ 339.00\end{array}$ & $\begin{array}{l}\$ 84.37 \\
\$ 197.37 \\
\$ 310.37 \\
\$ 412.37\end{array}$ & $\begin{array}{l}\$ 51.04 \\
\$ 164.04 \\
\$ 277.04 \\
\$ 390.04\end{array}$ & & \\
\hline
\end{tabular}




\begin{tabular}{|c|c|c|c|c|}
\hline \multirow{2}{*}{ Province } & \multicolumn{2}{|c|}{ Child Benefit } & \multicolumn{2}{|c|}{ Child Day Care } \\
\hline & Maximum Benefit (annual) & Income thresholds & Major subsidy program & Parent fees \\
\hline $\begin{array}{l}\text { Manitoba } \\
\text { (Manitoba Child Benefit) }\end{array}$ & $\begin{array}{l}\text { Under age } 18 \\
1 \text { child: } \$ 420 \\
2 \text { children: } \$ 840 \\
3 \text { children: } \$ 1,260 \\
4 \text { children: } \$ 1,680 \\
5 \text { children: } \$ 2,100 \\
6 \text { children: } \$ 2,520\end{array}$ & $\begin{array}{l}\text { Income tested } \\
\text { Below } \$ 15,000 \text { : full benefit } \\
\text { Between } \$ 15,001 \text { and } \$ 20,435- \\
\$ 25,864 \text { (depending on the number } \\
\text { of children), reduced amount }\end{array}$ & $\begin{array}{l}\text { Capita grants: start-up assistance } \\
\text { Operating grants }\end{array}$ & $\begin{array}{l}\text { Maximum daily fees are } \\
\text { administratively set for } \\
\text { provincially funded child care } \\
\text { services. } \\
\text { Centers and trained provider } \\
\text { Infants: } \$ 30.00 \\
\text { Pre-school: } \$ 20.80 \\
\text { School-age (full day): } \$ 20.80 \\
\text { School-age (half day): } \$ 10.30 \\
\text { Family child care } \\
\text { Infants: } \$ 22.20 \\
\text { Pre-school: } \$ 18.20 \\
\text { School-age (full day): } \$ 18.20 \\
\text { School-age (half day): } \$ 10.30\end{array}$ \\
\hline Saskatchewan & --- & --- & $\begin{array}{l}\text { Capital and start-up grants } \\
\text { Early Childhood Services Grants: } \\
\text { wages and operating costs subsidies }\end{array}$ & No administratively set fee \\
\hline $\begin{array}{l}\text { Alberta } \\
\text { (Alberta Child Benefit and } \\
\text { Alberta Family } \\
\text { Employment Tax Credit) }\end{array}$ & $\begin{array}{l}\text { Under age } 18 \\
\text { Alberta Child Benefit } \\
1 \text { child: } \$ 1,100 \\
2 \text { children: } \$ 1,650 \\
3 \text { children: } \$ 2,200 \\
4 \text { children and more: } \$ 2,750 \\
\text { Alberta Family Employment } \\
\text { Tax Credit } \\
1 \text { child: } \$ 763 \\
2 \text { children: } \$ 1,457 \\
3 \text { children: } \$ 1,873 \\
4 \text { children and more: } \$ 2,012\end{array}$ & $\begin{array}{l}\text { Income tested } \\
\text { Alberta Child Benefit: } \\
\text { Below } \$ 25,500 \text { : full benefit } \\
\text { Between } \$ 25,500 \text { and } \$ 41,220 \text {, } \\
\text { reduced amount. } \\
\text { Alberta Family Tax Credit: } \\
\text { Below } \$ 2,760 \text { : no benefit } \\
\text { Between } \$ 2,760 \text { and } \$ 60,325- \\
\$ 91,550 \text { (depending on the number } \\
\text { of children). }\end{array}$ & $\begin{array}{l}\text { Accreditation Funding for Child Care } \\
\text { programs: includes staff support } \\
\text { funding, benefit contribution grant, and } \\
\text { professional development grant. }\end{array}$ & No administratively set fee \\
\hline British Columbia & $\begin{array}{l}\text { Under age } 6 \\
\$ 660 \text { per child }\end{array}$ & $\begin{array}{l}\text { Income tested } \\
\text { Below } \$ 100,000 \text { : full benefit }\end{array}$ & Child Care Minor Capital Funding & No administratively set fee \\
\hline
\end{tabular}




\begin{tabular}{|c|c|c|c|c|}
\hline \multirow{2}{*}{ Province } & \multicolumn{2}{|c|}{ Child Benefit } & \multicolumn{2}{|c|}{ Child Day Care } \\
\hline & Maximum Benefit (annual) & Income thresholds & Major subsidy program & Parent fees \\
\hline $\begin{array}{l}\text { (B.C. Early Childhood Tax } \\
\text { Benefit) }\end{array}$ & & $\begin{array}{l}\text { Between } \$ 100,00 \text { and } \$ 150,000 \text {, } \\
\text { reduced amount } \\
\text { A separate child care subsidy is } \\
\text { available for low-income families } \\
\text { earning } \$ 40,000 \text { or less. }\end{array}$ & $\begin{array}{l}\text { Child Care Operating Fund } \\
\text { Supported Child Development Fund: } \\
\text { including staff training subsidies }\end{array}$ & \\
\hline
\end{tabular}

Sources: Sarlo, C., 2016, “Child Care in Canada: Examining the Status Quo in 2015,” Fraser Institute; Friendly, M., C., Bethany, M. Lyndsay, F. Barry, 2015, “Early Childhood Education and Care in Canada 2014;" Canada Department of Finance; Newfoundland and Labrador, Department of Advanced Education and Skills;

Prince Edward Island Department of Family and Human Services; Nova Scotia Community Services; New Brunswick Finance; Retraite Quebec; Ontario Ministry of Children and Youth Services; Manitoba Child Benefit; Alberta Child Benefit; British Columbia Caring for Young Children. 
Annex III. Canada: Illustrative Calculations of Marginal Benefit Rates by Province 1/ (In Canadian dollars; unless otherwise indicated)

\begin{tabular}{|c|c|c|c|c|c|c|c|c|c|c|c|c|c|c|c|c|c|c|c|c|}
\hline \multirow[b]{2}{*}{ Single or double earners? } & \multicolumn{2}{|c|}{ British Columbia } & \multicolumn{2}{|c|}{ Alberta } & \multicolumn{2}{|c|}{ Saskatchewan } & \multicolumn{2}{|c|}{ Manitoba } & \multicolumn{2}{|c|}{ Ontario } & \multicolumn{2}{|c|}{ Quebec } & \multicolumn{2}{|c|}{ New Brunswick } & \multicolumn{2}{|c|}{ Nova Scotia } & \multicolumn{2}{|c|}{ Prince Edward Island } & \multicolumn{2}{|c|}{ Newfoundland } \\
\hline & Single & Double & Single & Double & Single & Double & Single & Double & Single & Double & Single & Double & Single & Double & Single & Double & Single & Double & Single & Double \\
\hline \multicolumn{21}{|l|}{ Low income families } \\
\hline Taxable income (1) & 19,000 & 38,000 & 19,000 & 38,000 & 19,000 & 38,000 & 19,000 & 38,000 & 19,000 & 38,000 & 19,000 & 38,000 & 19,000 & 38,000 & 19,000 & 38,000 & 19,000 & 38,000 & 19,000 & 38,000 \\
\hline Income taxes paid (2) & 1,583 & 1,583 & 1,184 & 1,184 & 1,476 & 1,476 & 2,194 & 2,194 & 1,583 & 1,583 & 1,673 & 2,223 & 2,024 & 2,024 & 2,054 & 2,054 & 2,207 & 2,207 & 1,965 & 1,965 \\
\hline \multicolumn{21}{|l|}{$\begin{array}{l}\text { Federal } \\
\text { Provincial }\end{array}$} \\
\hline Childcare costs (3) & 0 & 28,152 & 0 & 23,016 & 0 & 16,560 & 0 & 10,824 & 0 & 28,632 & 0 & 3,937 & 0 & 17,712 & 0 & 19,680 & 0 & 14,592 & 0 & 20,832 \\
\hline Child benefit (4) & 15,274 & 14,408 & 17,121 & 14,993 & 14,338 & 13,368 & 13,654 & 12,870 & 18,133 & 15,531 & 13,654 & 12,874 & 15,204 & 13,628 & 15,479 & 12,929 & 13,819 & 13,066 & 15,208 & 13,749 \\
\hline Federal & 13,654 & 12,788 & 13,654 & 12,714 & 13,654 & 12,768 & 13,654 & 12,870 & 13,654 & 12,788 & 13,654 & 12,874 & 13,654 & 12,847 & 13,654 & 12,851 & 13,654 & 12,872 & 13,654 & 12,839 \\
\hline Provincial & 1,620 & 1,620 & 3,467 & 2,279 & 684 & 600 & 0 & 0 & 4,479 & 2,743 & 0 & 0 & 1,550 & 780 & 1,825 & 78 & 165 & 194 & 1,555 & 910 \\
\hline Net income $(1-2-3+4)$ & 32,691 & 22,673 & 34,937 & 28,793 & 31,862 & 33,332 & 30,460 & 37,852 & 35,550 & 23,316 & 30,981 & 44,714 & 32,180 & 31,892 & 32,425 & 29,195 & 30,612 & 34,267 & 32,243 & 28,952 \\
\hline Marginal benefit rates 1 / & $\ldots$ & -0.53 & $\ldots$ & -0.32 & $\ldots$ & 0.08 & $\ldots$ & 0.39 & $\ldots$ & -0.64 & $\ldots$ & 0.72 & $\ldots$ & -0.02 & $\ldots$ & -0.17 & $\ldots$ & 0.19 & $\ldots$ & -0.17 \\
\hline \multicolumn{21}{|l|}{ Middle income families } \\
\hline Taxable income (1) & 40,000 & 80,000 & 40,000 & 80,000 & 40,000 & 80,000 & 40,000 & 80,000 & 40,000 & 80,000 & 40,000 & 80,000 & 40,000 & 80,000 & 40,000 & 80,000 & 40,000 & 80,000 & 40,000 & 80,000 \\
\hline Income taxes paid (2) & 5,843 & 9,988 & 6,434 & 8,868 & 6,936 & 9,712 & 7,788 & 12,608 & 5,793 & 8,378 & 7,663 & 14,093 & 7,206 & 10,464 & 7,691 & 10,934 & 7,736 & 11,532 & 7,094 & 10,219 \\
\hline \multirow{2}{*}{\multicolumn{21}{|c|}{$\begin{array}{l}\text { Federal } \\
\text { Provincial }\end{array}$}} \\
\hline & & & & & & & & & & & & & & & & & & & & \\
\hline Childcare costs (3) & 0 & 28,152 & 0 & 23,016 & 0 & 16,560 & 0 & 10,824 & 0 & 28,632 & 0 & 4,323 & 0 & 17,712 & 0 & 19,680 & 0 & 14,592 & 0 & 20,832 \\
\hline Child benefit (4) & 14,713 & 7,818 & 15,793 & 8,347 & 13,909 & 7,773 & 14,197 & 7,939 & 16,139 & 7,698 & 13,338 & 8,023 & 14,077 & 7,926 & 13,602 & 7,843 & 13,525 & 7,907 & 14,172 & 7,802 \\
\hline Federal & 13,093 & 6,498 & 13,172 & 7,725 & 13,240 & 7,773 & 13,355 & 7,939 & 13,086 & 7,698 & 13,338 & 8,023 & 13,277 & 7,816 & 13,342 & 7,843 & 13,348 & 7,877 & 13,262 & 7,802 \\
\hline Provincial & 1,620 & 1,320 & 2,620 & 622 & 669 & 0 & 842 & 0 & 3,053 & 0 & 0 & 0 & 800 & 109 & 260 & 0 & 176 & 30 & 910 & 0 \\
\hline Net income $(1-2-3+4)$ & 48,870 & 49,678 & 49,359 & 56,463 & 46,973 & 61,501 & 46,409 & 64,507 & 50,346 & 50,688 & 45,675 & 69,607 & 46,871 & 59,750 & 45,911 & 57,229 & 45,789 & 61,783 & 47,078 & 56,751 \\
\hline Marginal benefit rates 1 / & $\ldots$ & 0.02 & $\ldots$ & 0.18 & $\ldots$ & 0.36 & $\ldots$ & 0.45 & $\ldots$ & 0.01 & $\ldots$ & 0.60 & $\ldots$ & 0.32 & $\ldots$ & 0.28 & $\ldots$ & 0.40 & $\ldots$ & 0.24 \\
\hline \multicolumn{21}{|l|}{ High income families } \\
\hline Taxable income (1) & 97,000 & 194,000 & 97,000 & 194,000 & 97,000 & 194,000 & 97,000 & 194,000 & 97,000 & 194,000 & 97,000 & 194,000 & 97,000 & 194,000 & 97,000 & 194,000 & 97,000 & 194,000 & 97,000 & 194,000 \\
\hline Income taxes paid (2) & 22,722 & 39,964 & 23,882 & 42,530 & 26,003 & 46,292 & 28,199 & 51,942 & 23,902 & 41,642 & 29,266 & 54,502 & 27,649 & 49,021 & 28,644 & 50,954 & 25,350 & 47,876 & 26,818 & 47,674 \\
\hline \multicolumn{21}{|l|}{ Federal } \\
\hline Provincial & & & & & & & & & & & & & & & & & & & & \\
\hline Childcare costs (3) & 0 & 28,152 & 0 & 23,016 & 0 & 16,560 & 0 & 10,824 & 0 & 28,632 & 0 & 9,080 & 0 & 17,712 & 0 & 19,680 & 0 & 14,592 & 0 & 20,832 \\
\hline Child benefit (4) & 8,866 & 3,000 & 8,154 & 3,146 & 7,733 & 3,361 & 7,858 & 3,683 & 7,613 & 3,096 & 7,919 & 3,829 & 7,940 & 3,516 & 7,884 & 3,626 & 7,696 & 3,451 & 7,780 & 3,439 \\
\hline Federal & 7,546 & 3,000 & 7,612 & 3,146 & 7,733 & 3,361 & 7,858 & 3,683 & 7,613 & 3,096 & 7,919 & 3,829 & 7,827 & 3,516 & 7,884 & 3,626 & 7,696 & 3,451 & 7,780 & 3,439 \\
\hline Provincial & 1,320 & 0 & 542 & 0 & 0 & 0 & 0 & 0 & 0 & 0 & 0 & 0 & 113 & 0 & 0 & 0 & 0 & 0 & 0 & 0 \\
\hline Net income $(1-2-3+4)$ & 83,144 & 128,884 & 81,272 & 131,600 & 78,730 & 134,509 & 76,659 & 134,917 & 80,711 & 126,822 & 75,653 & 134,247 & 77,291 & 130,783 & 76,240 & 126,992 & 79,346 & 134,983 & 77,962 & 128,933 \\
\hline Marginal benefit rates 1 / & $\ldots$ & 0.47 & $\ldots$ & 0.52 & $\ldots$ & 0.58 & $\ldots$ & 0.60 & $\ldots$ & 0.48 & $\ldots$ & 0.60 & $\ldots$ & 0.55 & $\ldots$ & 0.52 & $\ldots$ & 0.57 & $\ldots$ & 0.53 \\
\hline Memorandum items & & & & & & & & & & & & & & & & & & & & \\
\hline Federal tax rates (\%) & & & & & & & & & & & & & & & & & & & & \\
\hline Lowest bracket & 15.0 & 15.0 & 15.0 & 15.0 & 15.0 & 15.0 & 15.0 & 15.0 & 15.0 & 15.0 & 15.0 & 15.0 & 15.0 & 15.0 & 15.0 & 15.0 & 15.0 & 15.0 & 15.0 & 15.0 \\
\hline Second lowest bracket & 20.5 & 20.5 & 20.5 & 20.5 & 20.5 & 20.5 & 20.5 & 20.5 & 20.5 & 20.5 & 20.5 & 20.5 & 20.5 & 20.5 & 20.5 & 20.5 & 20.5 & 20.5 & 20.5 & 20.5 \\
\hline Third lowest bracket & 26.0 & 26.0 & 26.0 & 26.0 & 26.0 & 26.0 & 26.0 & 26.0 & 26.0 & 26.0 & 26.0 & 26.0 & 26.0 & 26.0 & 26.0 & 26.0 & 26.0 & 26.0 & 26.0 & 26.0 \\
\hline Provincial tax rates (\%) & & & & & & & & & & & & & & & & & & & & \\
\hline Lowest bracket & 5.1 & 5.1 & 10.0 & 10.0 & 11.0 & 11.0 & 10.8 & 10.8 & 5.1 & 5.1 & 16.0 & 16.0 & 9.7 & 9.7 & 8.8 & 8.8 & 9.8 & 9.8 & 8.2 & 8.2 \\
\hline Second lowest bracket & 7.7 & 7.7 & 12.0 & 12.0 & 13.0 & 13.0 & 12.8 & 12.8 & 9.2 & 9.2 & 20.0 & 20.0 & 14.8 & 14.8 & 15.0 & 15.0 & 13.8 & 13.8 & 13.5 & 13.5 \\
\hline Third lowest bracket & 10.5 & 10.5 & 13.0 & 13.0 & 15.0 & 15.0 & 17.4 & 17.4 & 11.2 & 11.2 & 24.0 & 24.0 & 16.5 & 16.5 & 16.7 & 16.7 & 16.7 & 16.7 & 14.6 & 14.6 \\
\hline Fourth lowest bracket & 12.3 & 12.3 & 14.0 & 14.0 & $\ldots$ & $\ldots$ & $\ldots$ & $\ldots$ & 12.2 & 12.2 & 25.8 & 25.8 & 17.8 & 17.8 & 17.5 & 17.5 & $\ldots$ & $\ldots$ & 15.8 & 15.8 \\
\hline
\end{tabular}

1/ Marginal benefits are calculated as the ratio of a change in net income to a change in family taxable income.

Annex III. Canada: Illustrative Calculations of Marginal Benefit Rates by Province 